\title{
طبائع الاستبداد وقابليّات الاستبعاد
}

\section{محمّد جمال طحّان}

الاستبداد كلمة مستبعدة ومنفية من دوائر المعارف، 1 ومخظور تداولها بين الناس، وممارسه يحرص على أن يبقيه مصدراً يهيط به الغموض من كل جانب حتى لا يتسنّى للناس تحقيق مقولة (اعرف عدوّك أولاً)، وبالتالي، حتى لا يتمكّنوا من التغلّب عليه.

إن الاستبداد، فضلاً عن أنه يحاول التملّص من التحديد لابساً أثواباً تمويهية متنوعة، فإن له أشكالاً متعددة تتطور وتتبدل، مع تقدم الحياة الإنسانية، بفضل ما يوفّره له منظّروه من أساليب جديدة. لذا لا بد لنا، في البدء، من تحديد معناه: أوّلاً في اللغة، لأن الإطلاق اللغوي غير المقنّن للعبارات، كثيراً ما يوقع في حُفر الفهم غير الواضح لما نريد قوله، وثانياً في الفكر العربي محاولين التّعرف إلى ما كانوا يعنونه بكلمة (استبداد)، وكيف كانوا يفكرون فيها. وأخيراً نحاول تحديد طبائع الاستبداد وقابليّات الاستعباد.

\section{أولاً: مفهوم الاستبداد}

الاستبداد، لغة، هو اسم لفعل (استبدَّ) يقوم به فاعلٌٌ (مستَبِدّ) ليتحكّم في موضوعه (المستَبدّ به). فلا بد أن يتجسّد الاستبداد في شخص أو فئة. يقال: (استبدَّ به: انفرد به. واستبدّ: ذهب. واستبد الأمر بفلان: غلبه فلم يقدر على ضبطه. واستبدَّ بأميره: غلب على رأيه، فهو لا يسمع إلا منه).2 فإذا كان الفاعل (شيئاً) يكون السبب إما نقصاً فيمن وقع عليه الفعل، أو قدرة كبيرة (للشيء) مما لا طاقة للمفعول على رده. وهذا من قبيل استبداد المال والخزافة، أو من قبيل استبداد النفس بالعقل، فينجرّ المرء إلى المجد الزائف وتفسد أخلاقه. بمعنى آخر، تكون العلة إما لعجز طارئ في المغلوب، أو لضعف طبيعي فيه.

$$
\text { * * المدير الإداري لجمعية العاديات السورية، عضو التحاد الكّتاب العرب، عضو اتحاد الصحفيين، باحث في الفكر العربي. }
$$

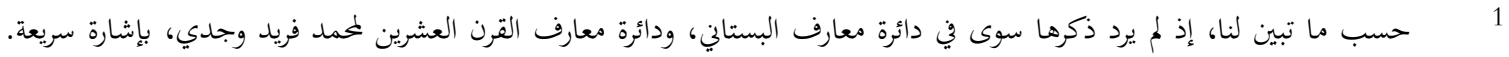

مادة (بدد).

$$
2
$$


ولما كنّا نستبعد مطلقاً أن يقوم شيء (بالفعل) فيغدو فاعلاً، وإنما يكون ذلك بجازاً لا يتم إلا عن طريق عاقل، لذا سنطرح هذا المعنى جانباً. أما إذا كان الفاعل (إنسانا) أوقع الفعل على نفسه بوساطة آخر، فيكون ذلك إما ثقة منه (بالآخر)، أو معرفة منه بنقصه عن الآخر، أو جهلاً منه في قدرته على سياسة نفسه. وفي هذه الحالات كلها نلاحظ أن العلاقة لا تتجاوز الفرد، من حيث تعامله مع الاستبداد، ويكون الاستبداد فرديّاً من طرف الفاعل والمفعول، وليس في ذلك إجحاف بالآخرين، وإن كان يوقع الذّم للنفس. أما إذا بحاوزت العلاقة بالاستبداد، الفرد الواحد، دخلت في باب الجماعة وكان هناك آخر. قال (ابن منظور): "استبدَّ فلان بكذا أي انفرد به، وفي حديث علي: كنّا نرى أن لنا في هذا الأمر حقاً فاستبددتم علينا. يقال: استبدَّ بالأمر يستبدّ به استبداداً إذا انفرد به دون غيره. "3 فعلى صعيد الاستحواذ يكون الانفراد بالشيء: امتلاكه بغير حق، وعلى صعيد الفكر يكون: الانفراد بالرأي فيما بحب المشورة فيه. فإذا انفرد شخص (أو مجموعة) برأي، وبطريقة ممارسة فحواه دون أصحاب العلاقة الآخرين، دخلنا في باب الاستبداد الاجتماعي.

وإذا كان معنى الاستبداد، في اللغة العربية، هو الانفراد (بالشيء)، يكون الانفراد بالحكم استبداداً به، وهذا هو المعنى الذي درج المفكرون على قصده في استعمالم كلمة (استبداد)، أثناء حديثهم عن أسلوب مستهجن للحكم. إن الانفراد بالحكم يرادفه بالإنجليزية (autarky)،4 وهو لا يختلف كثيراً عن الحكم المطلق (absolutism)، 5 أما كلمة (despotism) التي وضعت إزاء (استبدادية)، والتي نقلت عن الانكليزية وقريناما الفرنسية والألمانية والإيطالية، فهي التي يظهر أها تعبر عن جوهر معنى (الاستبداد) الذي نعنيه، والذي كان هو المقصود عند بعض المفكرين العرب في العصر الحديث، وإن كان بدرجات مختلفة من الوعي

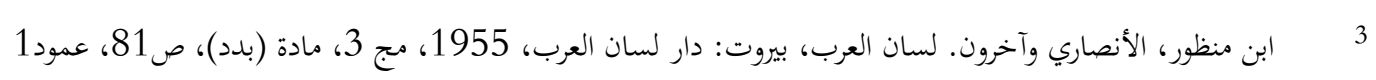

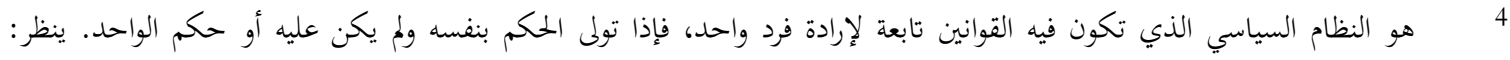

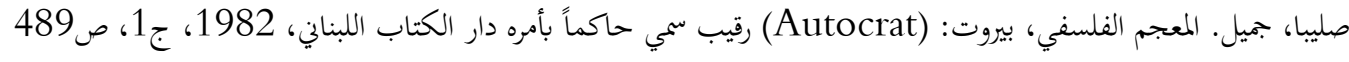
6 5

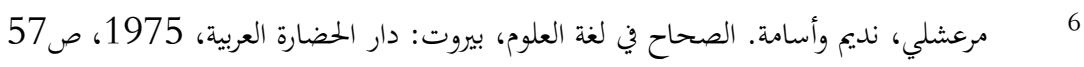


بمدى امتداد الاستبداد من أسلوب طاغ في الحكم (tyranny) وحسب، إلى كونه صيغة استبدادية للحياة في الدولة كلها (despotism).

إلا أن هذه الأخيرة يبدو أها ليست المصطلح الكامل الدلالة، المستخدم لدى المفكرين العرب، إذ ثمة كلمات أخرى مكافئة ها، بشكل أو بآخر، مثل كلمة الدكتاتورية (dictatorship)7 التي نجدها أوسع انتشاراً منذ عهد اليونان القدماء. أما كلمة الطغيان (tyranny) التي تعني استبداد الحاكم الذي يبني سياسته على العنف، فهي تشير في أغلب الأحيان، إلى ما يُفهم من الاستبداد عينه. 8 وكثيراً ما استخدم العرب كلمات (الظلم والتعسف والفساد...) للدلالة على ما يُنهم من الاستبداد، وهي كلمات عربية اشتُق معظمها من القرآن الكريم، ومع ذلك فمن الملاحظ أن هذه الكلمات لم تكن تُستعمل إلا لوصف نوع الحكم، ولم تتطرق إلى وصف الدولة بعناصرها كاملة. 9 ومن المرجح أن الفاصل بين تلك الكلمات كلها هو خيط رفيع جداً لا يمكن ملاحظته إلا عن طريق التجريد والنظر العلمي وحده (في تفاصيل اللغة)، 10 لأن الواقع يدلنا على جوهرية الأمر متجاوزاً شكليته: فما من حكم مطلق (absolutism) إلا ويصبح استبدادياً بخطوة واحدة تستدعيها لامشروطيته، وما من استبداد يستغني عن العنف لفرض مشيئته ما دام

غير مراقب، فيتحول بالضرورة إلى طغيان (Tyranny).

يصف لنا أفلاطون (Plato) 12 ذلك التحوّل الحتمي بقوله: (إن المستبد يستولي على السلطة بالقوة ويمارسها بالعنف، بعد ذلك يسعى أوّلاً إلى التخلص من أخطر أخصامه، ويُكثر من الوعود، ويبدأ بتقسيم الأراضي مما يجعله شعبياً ومحبوباً، وهو ما ينفكٌّ يفتعل حروباً ليظل الشعب بحاجة دائمة إلى قائد. وهذه الحروب تُفقِر المواطنين من خلال ما يدفعونه من ضرائب باهظة، فيضطرون إلى زيادة ساعات العمل مما لا

"دكتاتور: أصلا: حاكم روماني، معين لحكم ولاية في وقت الأزمة، وتشير الآن إلى الحاكم المطلق أو الأوتوقراطي". غربال، حمد شفيق

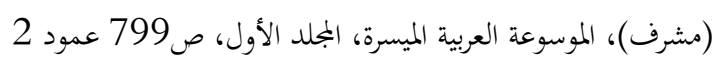
8

Webster, Third New International Dictionary of the English.

$$
\text { كثيراً ما يخلط بين (الحكومة) و(الدولة)، مع أخما يدلان على شيئين ختنلفين. }
$$

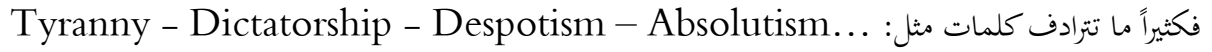

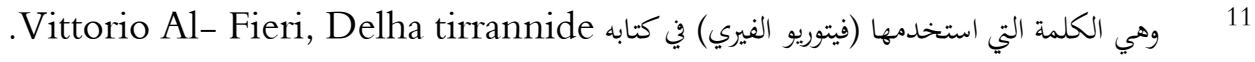

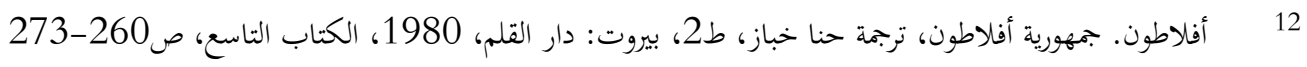


يدع لديهم وقتاً للتآمر على المستبد. والحرب تساعده على التخلص من معارضي سياسته، حيث يقدّمهم إلى الصفوف الأولى في المعركة. إن ذلك كله يدعو إلى استياء الجماهير، حتى أعوانه الذين رفعوه إلى السلطة، وهنا لا يجد أمامه إلاّ القضاء على المعارضة بما يملكه من وسائل العنف والقوة، فيزيد من تسلّحه، ومن حرسه الخاص من المرتزقة، مما يتطلّب نفقات طائلة، فيلجأ المستبد إلى مزيد من غب خزائن الشعب، الذي يدرك -بعد فوات الأوان- أنه وضع في حالة استعباد مسيَّس؛ فحكم القسوة، والإجرام، وضيق الحظيرة، وقلة الصبر على الآراء المخالفة، طبيعة ملازمة للحكومة المستبدة، ولا تلبث أن تنتشر هذه الطبائع في الدولة كلها وتعمّ العلاقات الاستبدادية المجتمع بهيئاته جميعها. إذا تساءلنا عن الصفات التي تقترن بالاسم (الاستبداد)، في الذهن، عند انطلاقه، نجد أنه حكم يدير ظهره لآراء الآخرين. وهذا يعني أن الاستبداد المقصود هو الاستبداد السياسي. أما إذا بحثنا عن الصفات الجوهرية الداخلة في التعريف فستقفز إلى الذهن مفردات: (إنسان - إنفراد - هوى) أي أن إنساناً ما،

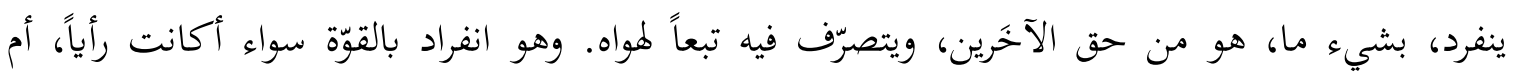
كانت مالاً، أم كانت سلاحاً، إلى غير ذلك من أنواع القوة، أو بحيازها كلّها معاً. وكلّما زادت صفة على سلى تلك الصفات الجوهرية، قلَّ من ينطبق عليهم الاسم. وكلّما عرفنا صفة إضافية من صفات المنفرد، زادت معرفتنا بنوع استبداده. فإذا أضيفت كلمة حكم إلى الاستبداد عرفنا أنّه استبداد سياسي، فإذا أضفنا (الرّأي) على الاسم قلنا أنّه استبداد فكري، وإذا أضفنا المال عرفنا أنه استبداد اقتصادي. وهكذا فإن للاستبداد أشكالاً كثيرة وامتداداً واسعاً، تبعاً لمن يصدر عنه الاستبداد أولاً، وتبعاً لمن يقع عليه ثانياً، ثم تبعاً للوسائل المستخدمة في ممارسته ثالثاً. فإذا كان من يقع عليه الاستبداد فرداً أو جماعة أو فئة أو طبقة أو كلهم مجتمعين، جاز تسمية ذلك استبداداً اجتماعياً، لأن الاستبداد إذا كان يهكم العلاقة بين اثنين فأكثر يكون اجتماعياً، مهما اختلفت مصادره ووسائله 13 فهو يشمل كل أشكال الاستبداد، مجتمعة أو متفرقة، لذلك فهو بعيد، عن التحديد، وغامض.

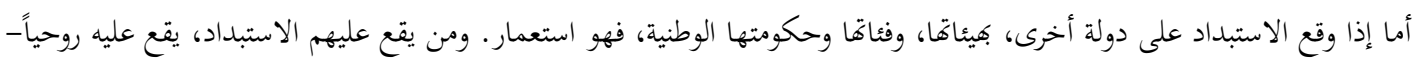
فكرياً، أو جسدياً مادياً، أو كلها معاً. 
ولكي نتمكّن من التحليق في سماء واضحة فإننا سنحاول فهم ما يسمى بالاستبداد الاجتماعي من خلال تفصيل الحديث عن الاستبداد من حيث وسيلته، لأن الهيئات الصادر عنها سرعان ما تتوحد في الحكم، فالقوة التغلبية يمكنها الاستبداد بالفكر أو بالاقتصاد أو بالحكم عن طريق العنف، إلاّ أن القوة (العضلية - العددية) سرعان ما تضلل أو تُشترى أو تُسيّس، فهي ليست إلاّ ملحقاً تابعاً للاستبداد المسيطر. حقاً كان لها في القديم سطوة، إلاّ أن قوة القبيلة العصبية سرعان ما أدرجت في التنظيم الجديد للمجتمع (الحكم). لقد تطورت أشكال التسلط إلى سيطرة الحكم، وما الحكم إلا مالك، بالدرجة الأولى، لوسائل الإكراه. كما يمكن لفئة من المفكرين، أو الأثرياء، أو الحكام الاستبداد فكرياً أو اقتصادياً أو سياسياً. وبما أن الاستبداد، من حيث الهيئات الصادر عنها، لا يمكنه الاستمرار إلا إذا توحّد، لذلك فإن هذه الهيئات تجتمع كلها، وتملك الأشياء كلها، فيصبح الاستبداد واحداً، من حيث الهيئة الصادر عنها، ولا يكون أمامنا من سبيل للقبض على ما يبدو أنه زئبقي إلا تقسيم الاستبداد إلى مسائله الأولية من حيث دراسة الوسائل، أو الأشياء، التي يستبد بها، ويستخدمها لإيقاع الاستبداد على الآخرين: هل هي الفكر، أو المال، أو السلطة السياسية التي يتبعها العسكر؟

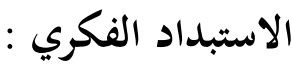

بداية نجد لزاماً علينا أن نحدد المقصود بالفكر، ونعد المسائل التي يمكن أن يطويها بين جناحيه، من غير أن يعد ذلك نشازاً عن سياقه العام، ومن غير أن يكون ما يدرج تحته حيازة غير شرعية لما هو من حق الآخرين.

الفكر ما ليس فعلاً مادياً. إنه فعلٌٌ ذهني يتحرك في المعقولان، فيؤثر في مفعوله تأثيراً مادياً، أو هو المعقولات إذا أردنا التدليل على الموضوع الذي تفكر فيه النفس؛ فهو إعمال العقل في الأشياء للوصول إلى معرفتها، ويُطلق على الظواهر المتعلقة بالحياة العقلية دون المادية، وهنا بيت القصيد.

فإذا كان الدين، في جانبه الروحي، عقائد ومشاعر، أي جملة من الإدراكات والاعتقادات، وكان العلم إدراكاً يتفق الناس في الحكم على مسائله، استناداً إلى علاقات موضوعية يكشف عنها تدريجياً، وكانت التربية هي تنمية الشخصية (من النواحي الجسمية والخلقية والعقلية) عن طريق تعليم الإنسان كيفية استخدام 
ملكاته أحسن استخدام؛ إذا كان الأمر كذلك، فإن الإدراك هو ما يجمع تلك المسائل كلها تحت قضية واحدة هي حركة في الفكر، وعمل فكري. إن كون هذه المسائل ظواهر فكرية يجعل جمعنا بينها أمراً مكناً،

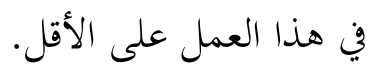

وكل استبداد باسم الدين أو العلم أو التربية يدخل في نطاق الاستبداد الفكري؛ إذ يتم التحكم في عقول الناس عن طريق سلطة وسائل الإعلام وسلطة البحث والتربية والتعليم، ومالكي زمام الإرشاد الديني، ولكنّ "عدم التسامح يبلغ أوجه مع النظم الدكتاتورية القائمة على عوامل تقنية، حيث تتبنى فئة صغيرة

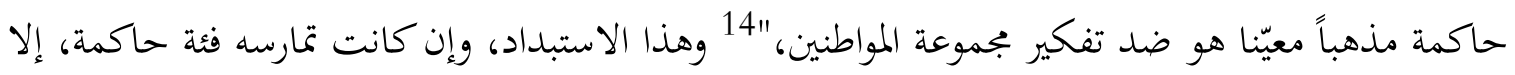
أنه يبقى، مع ذلك، استبداداً فكرياً قد تقوم به أي مؤسّسة أخرى خارج المؤسّسة السياسية. لذلك فإننا نفضل أن نطلق عليه كلمة "الاستلاب" تمييزاً له المصدر السياسي الأساسي للاستبداد.

\section{الاستبداد الاقتصادي:}

كما لا يجوز إنكار سلطة رأس المال حين يمكن لمجموعة ما أن تستغل المجتمع عن طريق الاستبداد بالثروة، حيث يشتري الأثرياء حياة الفقراء، عن طريق إرباكهم الدائم الضار في الركض وراء لقمة العيش، وهذا ما تنبه إليه كثيرون من مفكري القرن التاسع عشر الميلادي ولا سيما (ماركس). ولا نرى أننا نغالي إذا قلنا أن الاستبداد الاقتصادي يحجب التفكير -بطريقة غير مباشرة- مما يجعل الإنسان عبداً يرزح تحت

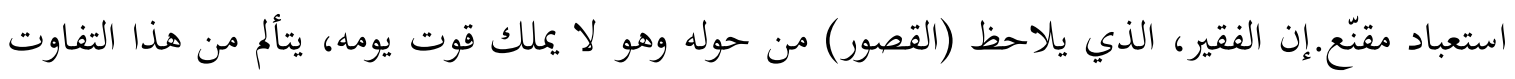
الكبير بينه وبين سواه في تحصيل المال، بالرغم من أنه يعمل أكثر منهم. وهذا التفاوت لا يقتصر خلقه على فئة متخمة بالثراء، بل تقوم به السلطة السياسية الاستبدادية أيضاً. لذلك، تمييزاً بين الاستبدادين، وتوضيحاً للاستبداد المالي الذي تصنعه أجهزة الحُكم، فإننا نسميه "الاستغلال".

والاستبداد، الذي اتفقنا على تسميته اجتماعياً كله (من حيث من يقع عليهم) والذي يرزح تحت سطوته من ندعوهم "المقهورين"، موجود في كل مكان، ابتداءً من الأسرة التي تعطل (الأنا) لصالح (الأنا الأعلى) فيبدأ استبطان (introspection) الطفل المحرَّات ويساعد الأسرة في كبت دوافعه. ولا يكتفي 14 
المثل الأعلى الاجتماعي بذلك، بل يظل يمارس رقابة دائمة تشجع قبول الإكراه، تصطنع النماذج، وتنمي الشعور الدائم بالذنب، وتخلق قلق مديونية الإنسان لمخيطه. ويستمر الاستبداد في المدرسة متمثلاً في صورة المعلِّم والموجِّه والمدير، الذين يتقمصون وظائف الأب والأم والزّوج والأخ الأكبر والذّكر، يستمر هؤلاء في ممارسة الضغط بترتيبة متشاهة. ثم تأتي الشركات والهيئات، والناطقون باسم الدين، وباسم المعلم، وباسم القانون تأتي هذه المؤسّسات محيطة بالأدوار التي يقوم بها الفرد في حياته كلها، وتمارس عليه استبداداً فكرياً واقتصادياً، إلى أن تتوّج الاستبدادَ السلطة السياسية.

\section{الاستبداد السّياسي:}

يبقى ثمة شيء يجب أن يقال: إن تلك الاستبدادات: الفكرية، والاقتصادية، وإن كان لها أثر كبير في المجتمع، فضلاً عن أها تمهد للاستبداد السياسي وتدعمه، إلاّ أها لا تملك قوة تنفيذية إلا بقدر ما يسمح به الاستبداد السياسي، بعد أن يتمكن من السيطرة، لأن كل المؤسسات، في الحكم الاستبدادي، ما هي إلاّ تابع يدخل ضمن نطاق التنظيم الذي تسيطر عليه الحكومة. فما الاغتراب الثقافي والاستغلال الاقتصادي، والاستلاب النفسي، إلا من صنع السلطة السياسية التي تملك القوة وتسعى للسيطرة على إمكانيات الدولة

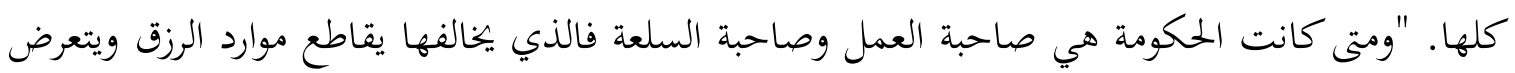
للجوع والانتقام على يد القانون"، 15 فهي سلطة مستبدة، وتممي استبدادها عن طريق جمع القوات كلها في قبضة واحدة: الفكر، والمال، والسلطة العسكرية، القائمة على احتكار إمكانية استخدام السلاح من قِبَّل فئة اجتماعية واحدة.

إن الاغتراب هو سياسي أكثر من أن يكون متمثلاً في الاستغلال الاقتصادي أو التضليل الفكريالديني-الأيديولوجي، لأن السياسي يشملهما. والدولة الاستبدادية -المعني هنا كل الأفراد والجماعات في مكان ما- هي التي تسمح للحكومة بوضع التمايزات الطبقية-الفئوية-النخبوية على شكل قانون يحمي القوي من الضعيف الذي قد ينفجر في أي لحظة. فالحاكم بأمره يصعد على عرش جبروته بتأييد شلة من 15 15 هاييك، الطريق إلى الرق. أوردها: العقاد، عباس محمود، فلاسفة الحكم في العصر الحديث، القاهرة: دار المعارف، 1950، ص122 
المنتفعين المتواطئين، يستمد منها القدرة المطلقة على قمع المعارضين، وعلى فرض الطاعة العمياء على الشعب، فيفرض نظرية واحدة، وزاوية واحدة للنظر، بجيث يظهر ألا سبيل أمام الناس سوى الطريقة التي يككم هو . بها.

والاستبداد في أوضح صوره هو استبداد سياسي، حيث تدور المعارك بين الحاكمين والمحكومين، بين مواطنين يملكون زمام السلطة وأجهزة الإكراه الاجتماعي، وبين مواطنين يخضعون لتلك السلطة ويتحركون كدمى متأثرين بوخز أجهزتما من غير أن يكون في إمكافم مقاومتها.

إن الحكم الاستبدادي يستغل المبدأ الحقوقي، الذي بموجبه تتتفظ الحكومة لنفسها بحق الإكراه، وتحوله إلى سلاح لإرهاب أصحاب وجهات النظر التي تعارض سياسة الحكومة، فيتسع الجهاز البوليسي ويمارس رقابة دقيقة، ويصبح الإعلام وقفاً على النظام، وتصبح كل ثقافة لا تخدم (عظمة النظام) مرفوضة وعميلة. إن الاستبداد يريد أن يتبع الشعب قادته المتحكمين، ويؤمن بما يؤمنون به من غير مناقشة، وأن يغير عقائده كلما رأى القادة وجوب ذلك. فالرأي هو رأي الحاكم، والقرار قراره وحده، ما دام هو الدولة، وبالطبع لا يككن أن يكون هناك رأي لآخر، وبالتالي، فلا بجال لأي فئة أو طبقة أو حزب آخر سوى حزب المستبد الذي يتمتع بإيديولوجيا رسمية تغطي جوانب الحياة الإنسانية جميعها تساعده رقابة بوليسية مشددة، ودعاية مركّزة، وتكون إدارة الاقتصاد متحكماً بها مركزياً.

وبماع القول: أن واحدأة، تساعده مجموعة، ممارِسة وحيدة المصدر تتميز بانعدام الحوار وإلغاء الآخرين، حيث لا مناقشة في أي قرار، ولا رقابة في ممارسات السلطة التي لا تتبع سوى هواها في إصدار القوانين وفي التحكم في مجرياتا، هذا هو شكل الحكم الاستبدادي. أما ما يكمن خلف هذا الشكل فهو شبكة عنكبوتية من العلاقات الاستبدادية هي التي تسمح له بالبروز إلى السطح، وهي التي يمكن تسميتها استبداداً تسمية مطلقة. 
أدرك بعض المفكرين طبيعة الاستبداد، بينما تلقف آخرون طعم السلطة فغرقوا في دوامتها. ولم يخلو الأمر من مؤلهي الممالك ومنظّري الملوك، إلا أنه لا يعنينا -هنا- أن نبحث مواقفهم، بقدر ما يهمنا أن نعرف كيف فهموا الاستبداد. بالطبع لن يمكننا أن نسبر غور فهم الجميع، وحسبنا أن نقف عند أهم المطات متأملين فحوى الاستبداد، منذ الفلاسفة الأول حتى مطلع العصر الحديث.

كانت مساهمة العرب في فهم الاستبداد، وفي مناهضته، مساهمة ضئيلة ومتأحّرة نسبياً، بالرغم من إرهاصاتم السابقة في هذا المجال. كانت المسألة تُعالج من وجهة نظر تحاول دفع الظلم بالمناداة للعودة إلى لي حظيرة الشرع-القانون، ولم يكن الاستبداد ليُدَرك إلا بتلمّس غامض في ممارسات الأمويين والعباسيين، إلى أن استبدّ الأتراك العثمانيون بالسلطة، استبداداً سافراً، وتطوّر الوعي بحيث أصبح من الممكن التفريق بين ما هو ديني وبين ما هو سياسي. وقد تزامن ذلك مع دخول مفاهيم الحرية السياسية وأفكار مقاومة الاستبداد مع الاجتياح الأوربي والبعثات العربية، وإن جرى ذلك -في البداية-باستحياء.

لقد كان الخلفاء الراشدون يعدّون أنفسهم خلفاء النبي صلى الله عليه وسلم في تسيير أمور الرعية، وخُطَبهم علاوة على ممارساهم، تدل على ذلك. فهذا (أبو بكر) رضي الله عنه في خطبة له يقول: "أيها الناس، إني قد ولّيت عليكم، ولست بخيركم، فإن رأيتموني على حق فأعينوني وإن رأيتموني على باطل فسدّدوني.."16 وما انتزع (معاوية) الخلافة من علي رضي الله عنه بدأ أنصاره يطالبون بإعادما إليه زاعمين

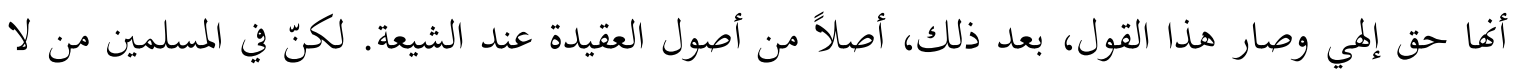
يوافق على كون الخلافة منصباً يُيب فيه الله أحداً من عباده عنه، بل يرون أن أمرها منوط بالمسلمين كافة،

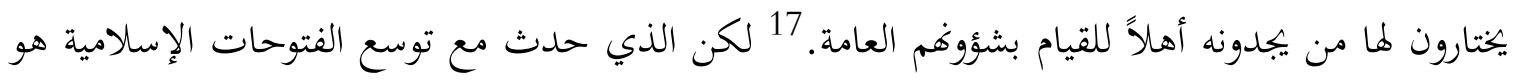
دخول جماعات مختلفة الأجناس والثقافات، وبدأت تتبلور مجموعة أفكار سياسية مكونة من التقاليد القَبَلية السابقة على الإسلام، والنظريات السياسية الهيلنستية والفارسية.

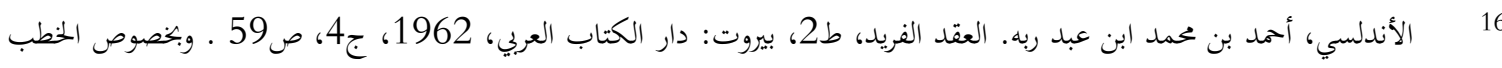

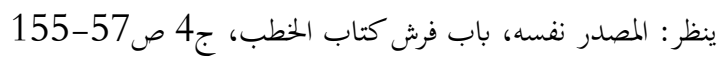
مروة، حسين. النزعات المادية في الفلسفة العربية الإسلامية. بيروت: دار الفارابي، ط4 كلابل 1984، ج1، ص389-399 
فضلاً عن الأفكار السياسية الإسلامية الأولى. فتشكّلت ثلاث صيغ أساسية تنصّ جميعها على تطبيق الشريعة، والمحافظة على الإسلام والدفاع عن مذهب السنّة والجماعة ضد الكفر:

- الأولى هي صيغة الفقهاء التي تتكوّن من آيات القرآن الكريم التي تتعلّق بالفكر السياسي، ثم سنّة

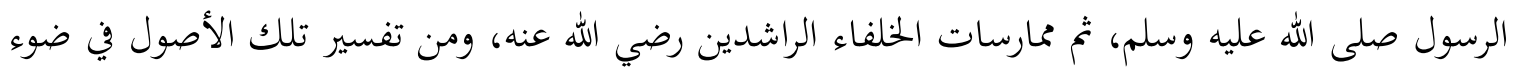

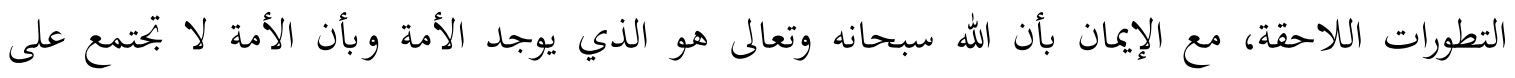

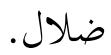

- والثانية وضعها رجال الإدارة وموجهو الحكّام والولاة، وهي تؤكد الحق الإلهي في الحكم، وهتم بممارسات السياسة أكثر من نظرياتا، وتزج قواعد الحكم الإسلامي بتقاليد الفرس في الملكك. - أما الثالثة فهي الصيغة التي وضعها الفلاسفة، وتدين بالكثير للفلسفة اليونانية، وتوّحد بين الإمام والملك والفيلسوف.

وعلى الصيغة الثانية اعتمد الأمويون في توطيد حكمهم، مستندين إلى النزعة الجبرية التي تقول: "إن

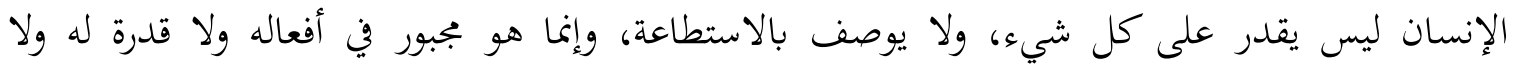
اختيار، وإنما يخلق الله الأفعال فيه على حسب ما يخلق في سائر الجمادات، وتُنسب إليه الأفعال بجازاً كما

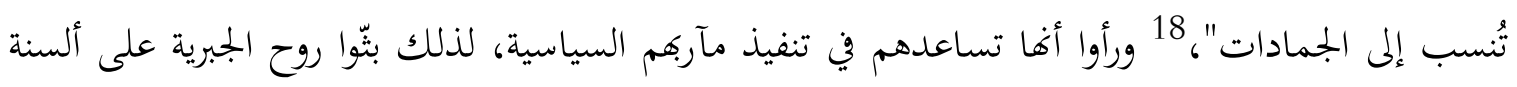
شعرائهم، يقول ثابت قطنة: - مابك

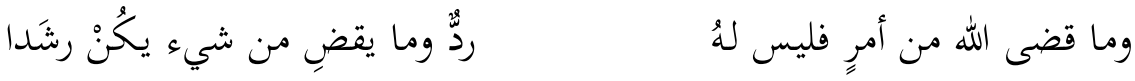

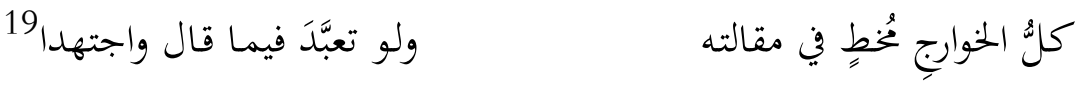

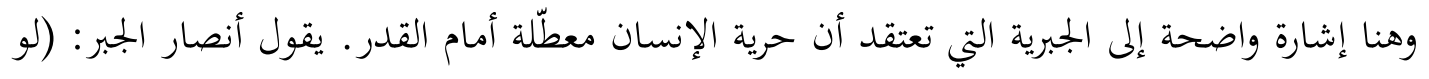

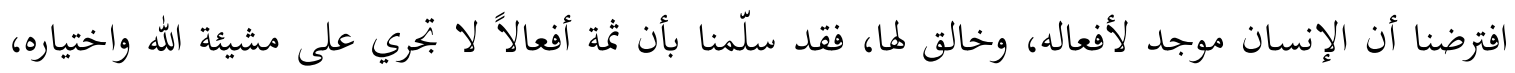

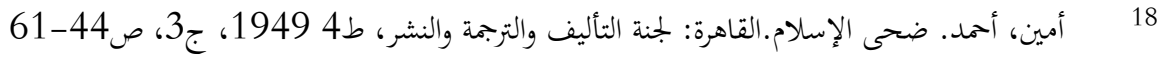

$$
\begin{aligned}
& 19
\end{aligned}
$$


وبالتالي فقد قلنا بوجود خالق آخر غير الله). 20 فلا بد إذن أن يكون الإنسان مسيّرًا غير غخيّر. وهذا ما يريده الحكّام، إذ به يصبح الناس على اعتقاد بأن حكم بني أمية، مهما ظلموا، قدر لا يمكن معارضته. وعلى هذا النحو جُرَّ الشعراء في عصر بني أمية فصُبغ شعرهم بما يروّج له من فكر جبري وجهمي. فهذا (جرير) يؤكد أن الله قد كتب خلافة الأمويين، وأنه لا مفرَّ منه ولا تبديل لكلماته، يقول: نالَ الخلافة إذ كانت لهُ قدراً كما أتى ربَّهُه موسى على قدَرِ 21

ففي العصر الأموي ساد الحكم المدني باسم الدين، حيث أضحت الخلافة في عهد الأمويين أقرب إلى السياسة منها إلى الدين، واستحالت على يد معاوية، إلى مُلك موروث، 22 متأثرة في ذلك بالنظام الذي كان سائداً في الدولتين: البيزطية والفارسية.

لقد استعمل الأمويون لفظ (الوالي) و(الأمير) بدلاً من (العامل) دلالة على السلطة التي أصبح يتمتع بها العمال، فبدأ استبداد الولاة مع (الحَجّاج) الذي استعمله (عبد الملك بن مروان) فاضطهد الموالي، مما ساعد على سقوط الحكم الأموي الذي وجد نفسه مفتقراً إلى حجة يتذرع بها لإثبات شرعية خلافته، بعد تخلّيه عن الشورى وقيام معارضة عنيفة في وجهه، فراح يستعين بالشعراء. وها هو (الأخطل) يمدح (عبد الملك بن مروان) في قصيدته "خفّ القطين" التي يقول في مطلعها: خفّ القطين، فراحوا منك، أو بكروا وأزعجتهم نويً، في صرفِها غِيَرُ

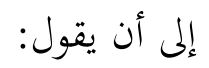
نوافلهُ أظفرهُ الله، فليهنئُ له الظفرُ إلى امرىڤٍ، لا تُعرّينا الخائضِ الغمرَ، والميمونِ طائرهُ خليفةِ اللهِ، يُستسقى بهِ المطرُ 


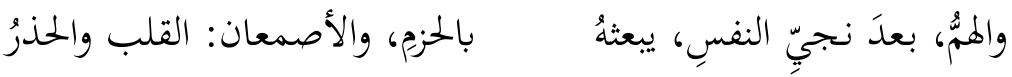

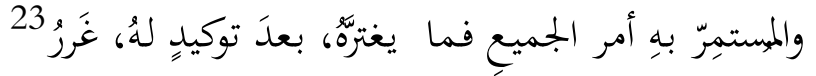

فهو يعلن حقوق الأمويين في وراثة الخلافة، وأن خلافتهم من الله وأن أمير المؤمنين هو خليفة الله في الأرض، يمفّه بالنصر المبين، ومن ثمَّ فإنَّ خلافته مقدسة مباركة.

$$
\text { ويقول الأحوص في الوليد بن عبد الملك: }
$$

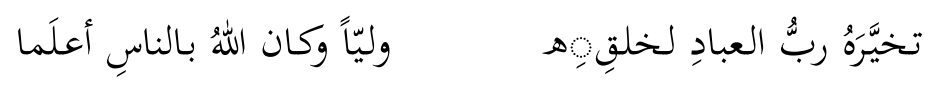

فهو يثبت أن الله اصطفاه واختاره لخلقه، وأنه وكل إليه شؤوغم يدبّرها كما يشاء.

$$
\text { أما حارثة بن بدر الغداني فإنه يقول في زياد بن أبيه: }
$$

$$
\text { فأنَأنتَ إمامُ معدلةٍ وقصدٍ }
$$

فهو يدعو معاوية خليفة الله، ويسبغ على زياد صفات دينية فهو إمام عادل ينصرهُ الله ويعينه. ويقول

$$
\text { جرير في أيوب بن سليمان ما يفيد المعنى نفسه: }
$$

$$
\text { أنتَ الخليفةُ للرحمنِ يعرفُهُ أهلُ الزَّبورِ وفي التوراة مكتوبُ }
$$

ولا ننسى خطبة زياد بالبصرة المسماة البتراء التي يقال أفها سميت كذلك لأفا لم تبدأ بحمد الله، يقول فيها: "أيها الناس، إنا أصبحنا لكم سادة، وعنكم ذادةً، نسوسكم بسلطان الله الذي أعطانا، ونذودُ عنكم

$$
233
$$


بفيء الله الذي خوَّلنا، فلنا عليكم السمعُ والطاعةُ فيما أحببنا، ولكم علينا العدل والإنصاف فيما وُولِّنا..."25 وكذلك رسالة عبد الحميد ابن يميى الكاتب عن مروان بن محمد إلى ابنه عبد الله حين وجّهه لمحاربة الضحاك ابن قيس الشيباني الخارجي، جاء فيها: "وإن كنتَ -والحمد لله- من دين الله وخلافته بحيث اصطنعك الله

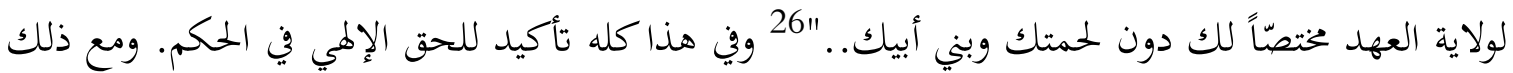
فإن الشعر ليس فكراً يُنظِّر، ولا يُعتمد عليه. ولكنَّه، على كل حال، كان صدئ لنظرية الحكم السائدة في العصر الأموي. وباستثناء سنوات قليلة فيها عمر بن عبد العزيز بسط العدل والشورى ورفع المظالم، فقد اتصفت الخلافة الأموية بحكم الفرد والبعد عن الشورى وعدم مسؤولية الخليفة أمام الشعب، والحكم الوراثي وانحصار الخلافة في البيت الأموي، وتصرّف الخليفة بأموال الدولة لصالح حكمه، والتمييز بين المواطنين، وقلب الخلافة إلى ملك دنيوي ينغمس فيه الخليفة في مظاهر الترف واللهو، والاعتماد على القوة والبطش في توطيد الملك ومحاربة الخصوم. - تلكوم

وقد كان الطغيان ظاهرة عامة زمن الحكومات الأموية والعباسية، حيث لم يكن للشعب حق الحدد من سلطة الحاكم لأنه غير مسؤول أمام أحد 27 "وكانت نظرية الحق الإلهي أو الحق المقدّس للملوك نظرية معترفاً هما منذ العهد العباسي، كما اعتُرفَ بها بعد ذلك في أمم أوروبا المسيحية."28 وقد حاول الحكام العباسيون الاستناد إلى نظرية الحق الإلهي مثل أسلافهم من الأمويين. فهذا أبو جعفر المنصور يقول في خطبة له بمكة: "أيها الناس إنما أنا سلطان الله في أرضه أسوسكم بتوفيقه وتسديده وتأييده وحارسه على ماله أعمل بمشيئه وإرادته" والأمثلة على ذلك أكثر من أن نتمكّن من حصرها في مثل هذه الدراسة. والمهم -هنا- أنه على 25 25 الجاحظ، أبو عثمان عمرو بن بحر. البيان والتبيين، تريرير عبد السلام هارون، القاهرة: مكتبة الخاني وبغداد: المهنى، 1961 ، ج2، ص

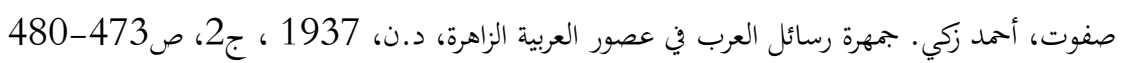

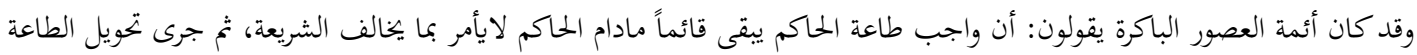
26

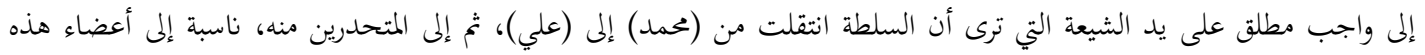

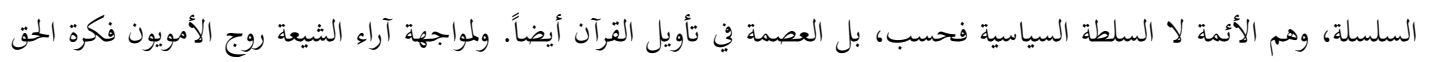

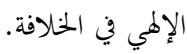
المقارنة: - الماوردي، الأحكام السلطانية. - الغزالي، إحياء علوم الدين. ابن تيمية، تقي الدين، السياسة الشرعية في إصلاح الراعي

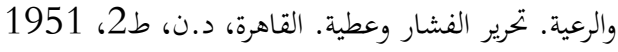

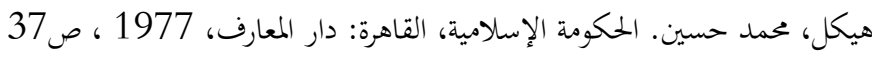


منوال الأمويين قد سار العباسيون (1258-750م) الذين كثر في فترة حكمهم الامتزاج بين العرب والموالي، واختلطت ثقافات الشعوب في فكر العرب وفي ممارساقم العامة، مما زاد في تسرّب العادات البيزطية والفارسية والجاهلية، فنشب صراع أدى إلى ظهور الشعوبية وظهور علم الكلام.

مع العباسيين ونشر أفكار الموالي، دخل الفرس والترك في الحكم، ولما قوي نفوذ الأتراك، في عهد المتوكل أضحى الخليفة كالأسير في أيديهم. وابتداء من القرن التاسع بدأت وحدة الإسلام تتفكك، واكتظت البلاد بجنود المرتزقة من الأتراك الذين اعتمد عليهم العباسيون، مما أدى، فضلاً عن عوامل أخرى، إلى نشوء دويلات مستقلة. فالموالي حاولوا استعادة مجدهم الفارسي، وقاموا بحركات (منها: القرامطة والبرامكة..) وكثر نفوذ الأجانب، وانتشر نظام ولاية العهد.

على الصعيد الفكري حاول المعتزلة الوقوف ضد الظلم "لا يحلّ لمسلم أن يخلي أئمة الضلالة وولاة

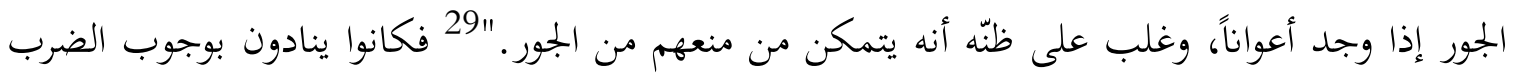
على الحاكم الظالم. وكان رأي الأشعرية هو "أن الإمام إنما يُُصَّب لإقامة الأحكام، وهو في جميع ما يتولاّه وكيل الأمة ونائب عنها، وهي من ورائه في تسديده وتقويمه وإذكاره وتنبيهه وأخذ الحق منه إذا وجب عليه،

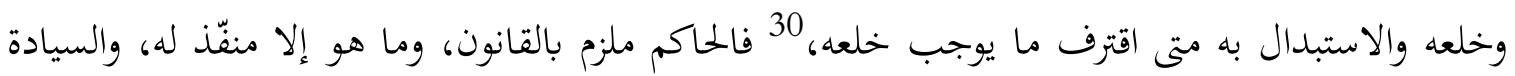
إنما هي للأمة التي بيدها أن تنحيّه عن منصبه إذا خالف القانون. مع ذلك، كان الشائع في الفكر العربيالإسلامي أن وجود حاكم، ولو كان فاسداً أفضل من عدمه.

وحين دخلت الفلسفة الإغريقية، تحوّلت المسألة من مصدر السلطة إلى كيفية ممارستها، حيث تأثرت الإمامة بجمهورية (أفلاطون) وأخلاق (أرسطو)، فتحول السؤال إلى: من يهكم وماذا يفعل؟ الحاكم عند الإغريق هو الفيلسوف، أما في الإسلام فهو النبي، معتمداً على أساس المجتمع، منفّذاً إرادة الله.

$$
\begin{aligned}
& 29 \text { } 29 \\
& 30 \text { } 30
\end{aligned}
$$


على يد (الفارابي) بدأت مرحلة توفيقية بين الدين والفلسفة في أثناء حديثه عن المدينة الفاضلة حيث طالب بالبي-الفيلسوف، سواء توافرت صفاته في شخص واحد أم في أشخاص عدّة. 31 فأساس السلطة في المجتمع الحاجة إلى قانون يحقق العدل ويمنع الظلم، لذلك يرفض (الفارابي) المدينة الضالة التي تقوم على القهر والغلبة حيث ليخيّل إلى كل كائن فيها أنه أهل لأن يكون له وحده الحق في الوجود الأفضل. 32 ونادى (ابن سينا) في كتاب الشفاء بوجوب طاعة الإمام الذي يتمتع بحق إلهي في الحكم. ومقابل انتعاش الشيعة عرّف (الماوردي) الخلافة في "الأحكام السّلطانية" بأنّا ضرورةٌ مستمدَّة من الشرع لا من العقل، فلا بد من خليفة لنبي يخلفه في حراسة الدين والدنيا معاً، ورأى أن القرآن يفرض طاعة أولي الأمر، وعلى هذا لا يجوز الخروج على الخليفة، وعنوان كتابه يدل على تركز السلطة في يد السلطان، فالدولة هي شخص الحاكم. 33 أما (الغزالي) فقد قال بعد شرح واجب الطاعة للحاكم ولو كان ظالماً، أن على المطيع ألا يؤيد الظلم بطاعته. وطالب بالابتعاد عن بلاط الحاكم الظالم، وصده إما بالكلام أو بالصمت، ويرى "أن السلطان الظالم عليه أن يكفّ عن ولايته، وهو إما معزول أو واجب العزل، وهو على التحقيق ليس بسلطان."34

لنلاحظ أن الحديث ما زال يجري عن الحاكم الظالم، وكيفية رد المظالم، وهو، وإن كان يمسّ معنى الاستبداد إلا أن الكلمة لم تكن مستخدمة بعد.

بعد انقسام السلطة بين الخليفة العباسي والأمير التركي، وبعد تدمير بغداد على يد المغول (1258م)، أصبح الخليفة ظلاً في بلاط سلاطين المماليك في مصر، وحدث تغيير في المؤسسات السياسية. إذ غدا الحكم استيلاءُ عسكرياً، والشرائعُ أوامرَ صادرة عن السلطان، ولُطّف ذلك بمظاهر احترام الإسلام والخليفة والعلماء.

في الواقع، لم يكن الخليفة سوى قاعدة معنوية للسلطان، فالسلطان، وقد استولى على الحكم، كان ينصبه الخليفة رسمياً ثم يعترف به أعيان الشعب في حفلة البيعة الشكلية. ربما من هنا بدأ الاستبداد بمعناه

$$
\begin{aligned}
& 31 \\
& 32 \\
& 333 \\
& 34
\end{aligned}
$$


الواسع، نسبياً، ومن هنا بدأ تسويغه على يد (ابن تيمية) الذي أفتى بأن الحاكم يجب أن يسلب السلطة ويفرض العدل، وذلك في كتاب خصصه لتبيين فتواه. لقد جعل ابن تيمية من قوة الإكراه جوهر الحكم، وضرورة من ضرورات المجتمع تنشأ بفعل استيلاء يضفي عليه عقد التشارك طابع الشرعية. فالحاكم، ولو كان ظالماً، خير من الفتنة وانحلال المجتمع، وللحاكم أن يفرض واجب الطاعة على رعاياه "أدوّا إليهم حقهم

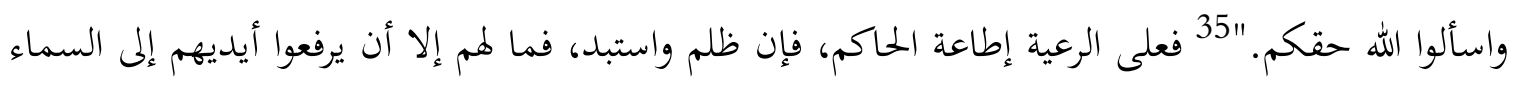
بالدعاء. ومع ذلك فإن وظيفة الحاكم عند ابن تيمية هي أن يفرض شرائع عادلة مستمدة من أوامر الله، وتستهدف خير الجماعة، فإن "كل ما خرج عن دعوة الإسلام والقرآن.. فهو من عزاء الجاهلية." تجزأت الخلافة إلى ممالك، فإن الانقسامات لا تنفي الوحدة الروحية.. إن الملوك كالخلفاء لهم الحق في أن يُطاعوا، وعليهم أن يستشيروا العلماء وقادة الرأي، ويجب أن يتسع مفهوم الشريعة ليشمل الظروف الحديثة لتصرّف الحاكم.

كان هذا هو رد الفعل عند ابن تيمية، على مظاهر الضعف والفساد الذي أصاب المجتمع، فأكّد ضرورة أولي الأمر لصالح الأمة، كما أكد الشورى، ولكن من غير أن يقيّد الحاكم بها ويراقب تنفيذها. وتبعه (ابن قيم الجوزية) فكان لآرائهما أثر في حركات الإصلاح التالية.

أما رأي (ابن خلدون) فيتمثل بقوله: (عندما يتمدّن شعب تظهر فيهم سلطة سياسية، والقوة أساس السلطان، فلا يقوم مُلك إلا بالثورات وانتصار القوي على الضعيف، ونشوء الدول لا يتم إلا على سواعد القبائل. وهكذا فكل دولة تقوم على العنف الذي هو حالة طبيعية للإنسان، ولا تقوم سلطة على تعاقد، والتغلب الملكي غاية العصبية وإذا بلغت العصبية إلى غايتها حصل للقبيلة الملك، إما بالاستبداد أو بالمظاهرة). 37 إذن فأمّا الحياة البدوية المتوحشة، وإما الخضوع لسلطان مطلق. أما إمكان قيام سلطة على أسس عقلية فهذا ما ينفيه ابن خلدون. وهو ينظر إلى الخلافة من هذه الناحية، يقول "الخلافة هي حمل

$$
\begin{aligned}
& 35 \text { ابن تيمية، تقي الدين. السياسة الشرعية في إصلاح الراعي والرعية، تحقيق الفشار وعطية، ط2، القاهرة: د.ن.، } 1951 \text { ، ص629 } \\
& 36 \\
& \text { ابن خلدون، عبد الرمن. المقدمة، تحتيق علي عبد الواحد وافي، القاهرة: لجنة البيان العربي، 1965، فصل } 17 \text { ، ص246 وما }
\end{aligned}
$$


الكافة على مقتضى النظر الشرعي في مصالحهم الأخروية والدنيوية الراجعة إليها"، 38 فالخلافة عنده ليست عنصراً إممانياً بقدر ما هي للمصلحة العامة، لحماية الدين وتنظيم المجتمع، ويجب أن تكون بيد أصحاب العصبية. إن الدولة العصبية، لدى ابن خلدون، تحمل سمتين أساسيتين هما: الاستبداد والعنف "وإنما المملك على الحقيقة لمن يستعبد الرعية ويجبي الأموال، ولا تكون فوق يده يد قاهرة."39 فالدولة تكون محكومة باستبداد قبيلة واحدة، ثم في الطور الثاني تنقلب إلى دولة فرد واحد ينفرد بالسلطة والمملك ويستبد، أما في الطور الأخير فيستبد بالدولة الموالي ومن وقع عليهم الاستبداد في الطور السابق.

بعد انتقال الخلافة إلى العثمانيين (1571م) أصبح الخليفة، الذي يجمع السلطات في يده، لقباً متوارثاً، اعتمده العثمانيون رمزاً للسلطة الدينية، كما تلقبوا بلقب السلطان رمزاً للسلطة المدنيّة. وكانت تلك بلك المرحلة وقفاً في الفكر العربي إلى أن جاء (الطهطاوي) الذي ربما قدّم أول فهم حديث للسياسة، ونقل التجربة السياسية الفرنسية في كتاب "تخليص الإبريز في تلخيص باريز" وشرحها وفق رؤيته لها. 40 وأسهم في أهم المقولات السياسية العربية الحديثة كالحرية، والوطن، والتربية السياسية، والإدارة، ووظائف الحكمم. فَهِهم (الطهطاوي) طبيعة النهضة السياسية بتقدّم القوتين: الحاكمة والمحكومة، مميزاً بين القوى: التشريعية، والقضائية، والتنفيذية، داعياً إلى ضرورة أن تكون دستورية. إلا أنه، بجكم علاقته مع (حمد علي) والي مصر، رأى أن الحاكم في مصر لا يمكن أن يكون بيد الشعب، وقَبِل بسلطة الحاكم، لكنه ألحّ على الحد الذي تضعه له القواعد الأخلاقية، فالشريعة فوق الحاكم، ولا بد أن يكون بين الحاكم والمحكوم علاقة حسن الطاعة وحسن الإرضاء "فالملك يتقلّد الحكومة لسياسة رعاياه على موجب القوانين"، 41 وهو يندّد بالملك الذي يستعبد رعيته "إن الملوك الذين لا يهمهم سوى أن يرهبهم الناس، فيستعبدون رعاياهم لجعلها أكثر خضوعاً، إنما هم وباء الجنس البشري"42 فلا يحق للملك أن يمنع الناس حقوقهم "كل عضو من أعضاء جمعية المملكة

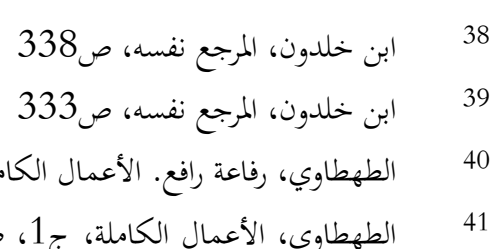

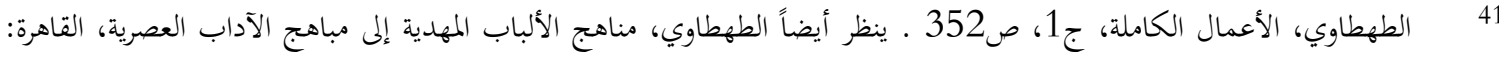

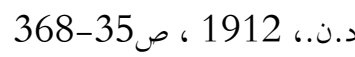
42 
يرخّص له أن يتمتع بجميع مباحات المملكة، فالتضييق عليه فيما يجوز فعله بدون وجه مرعي يعدّ حرماناً من

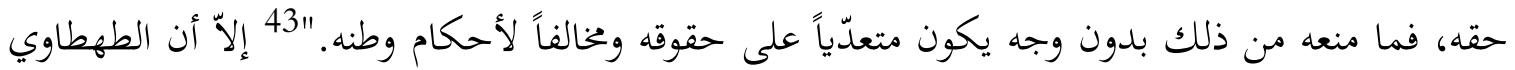
لا يخبرنا من الذي يضع تلك المخظورات، هل هو الملك؟ والوجوه المرعية، هل يحددها الملك بحسب ما يرتئيه من قوانين، أم يحددها الشعب؟ إن الطهطاوي أهمل دور الشعب في المشاركة بالحكم، وطالب بحكم فرد "إن وليّ الأمر هو رئيس أمته، وصاحب النفوذ الأول في دولته.. إنه خليفة الله في أرضه، وإن حسابه على ربّه، فليس عليه في فعله مسؤولية لأحد من رعاياه"، 44 فحكمه مستنِد إلى حق إلهي، ولا يمكن أن يراقبه أحد فيما يعمل. لقد كان الطهطاوي شجاعاً في (تخليص الابريز 1834م)، لكنه تراجع في (مناهج الألباب 1869م) أمام سلطة الحاكم ليجعله مسؤولاً أمام ذمته، وأمام الله فقط، ولا مسؤولية عليه أمام الشعب، إلا أن الطهطاوي، بالرغم من ذلك، حاول التصدي لنمط الحكم الشرقي في التفرد الاستبدادي بالسلطة، عن طريق إغراء الحاكم بحكم شعب من الأحرار "فمن ملك أحراراً طائعين، كان خيراً من يملك عبيداً مروعين." من البيّن أنّ الطهطاوي لم يستطع التّخلّص من فكرة (مملوكيّة الشعب) التي تتضمّن معنى الخضوع للمملوك بتحاه مالكه، مما جعل خير الدّين التّونسي يماول أن يتخلّص منها فيما بعد.

إنّ (خير الدّين التّونسي) يُدين الاستبداد بالسّلطة، ويرفض حكم الفرد "والمهمم أنّ لا يطلق أمر الوطن

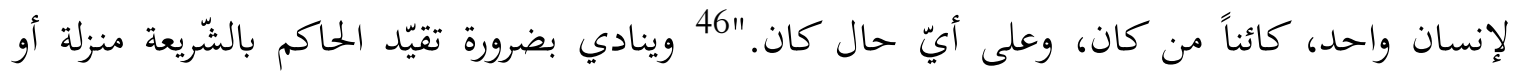
عقليّة، وبالمشورة من العلماء والأعيان لردعه عن عمل السّوء. ويرى أنّ المصلحة العامّة هي معيار الصّلاح و"معلوم أن تصرف الإمام في أحوال الرّعيّة لا يخرج عن دائرة المصلحة." 47 أما المصلحة الشّخصية للحاكم ودي

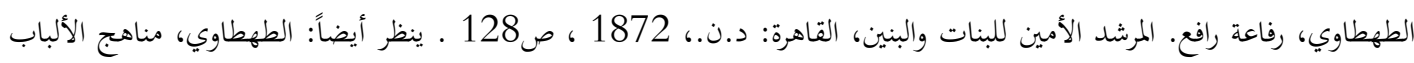

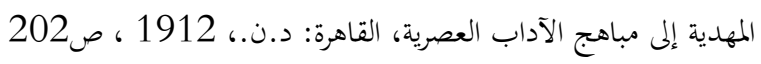

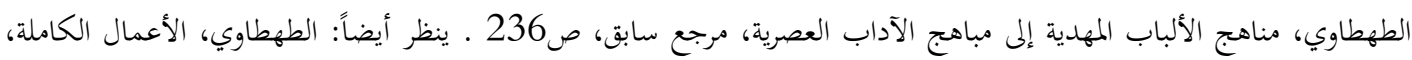

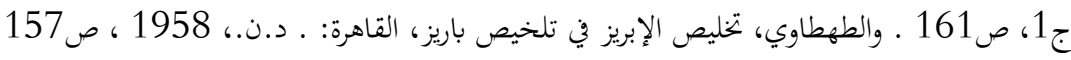

$$
45
$$

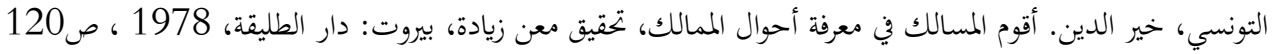

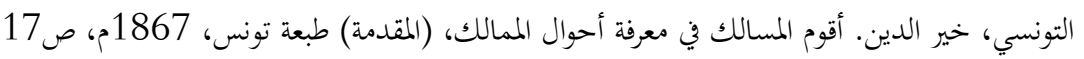


فهي دليل الفساد وقد ازدهرت الأمّة الإسلامية حين جرت سياستها على (مقتضيات المصلحة العامّة)، وتأخرت حين (تصرّف بعضهم بحسب الفوائد الشّخصية لا باعتبار مصلحة الدّولة والرّعية). والاستبداد هو عدم اعتبار رأي الجماعة، ومن هنا فهو الحكم تحت تأثير الموى الشخصي والتّصرف بمقتضى الشهوات." 48 إلاّ أن التونسي يجعل أهل الحل والعقد مجرد مفوضين للتصرف باسم السلطان فيقع

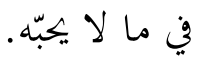

بعد ذلك جرى تطوير مفهوم الاستبداد على يد الأفغاني حيث شرح رأيه قائلاً: "بالقوة المطلقة

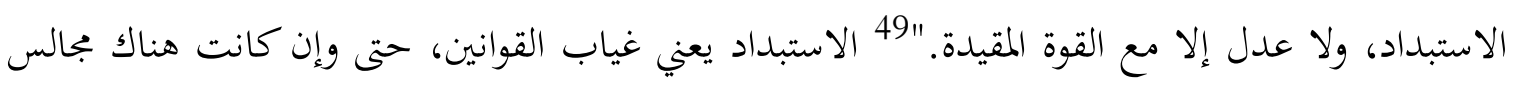
نيابية، فهذا لا يعني غياب الاستبداد "إن القوة النيابية لأي أمة كانت، لا يمكن أن تحوز المعنى الحقيقي، إلا إذا كانت من نفس الأمة. وأي مجلس نيابي يأمر بتشكيله ملك أو أمير أو قوة أجنبية محركها لها فاعلموا أن حياة تلك القوة النيابية الموهومة موقوفة على إرادة من أحدثها."50 فالمجلس الحقيقي يجب أن تشكله الأمة نفسها وإلا فهو مجرد مظهر شكلي لا قيمة فعلية له. فالاستبداد هو حكم الفرد الذي لا يشرك الأمة في الحكم، فيظلم ويستغل ولا يستند إلى قانون و"الإنسان الحقيقي هو الذي لا يهكم عليه إلا القانون الحق سلق المؤسَّس على دعائم العدل، الذي رضيه لنفسه"، 51 أما عدا ذلك يكون واقعاً تحت ضغط الاستبداد، ومحكوماً بملك لا يراعي القانون. والأفغاني يطالب باجتثاث الوباء، فالملك إذا حنث بقسمه وخان الدستور

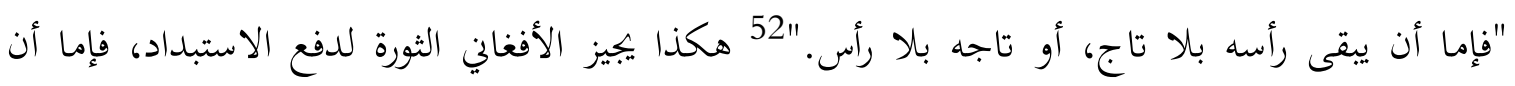
يتنازل المستبد عن الحكم وإما أن ينحى بالقوة.

أما (محمد عبده) فإنه يفرق بين الاستبداد والاستبداد المطلق، فيرفض الثاني ويقر الأول "إن الاستبداد المطلق منموع، منابذ لحكمة الله في تشريع الشرائع فإنه نبذ للدين وأحكامه، وسعيٌ خلف الهوى ومذاهبه،

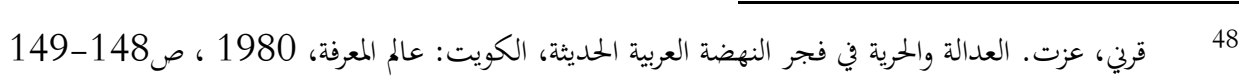

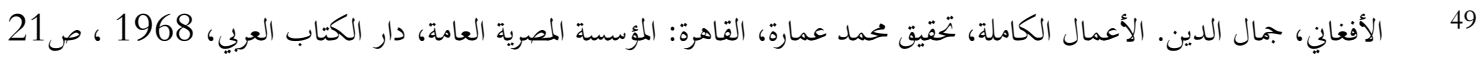

$$
50
$$

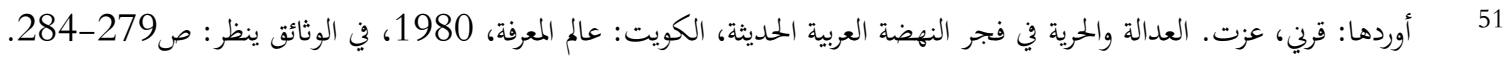

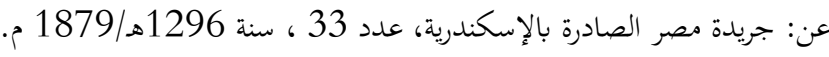

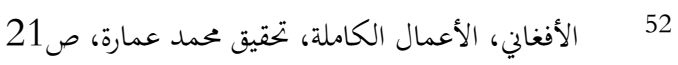


وذهابٌ لحفض كلمة الله العليا، وخرقٌّ لإجماع السّلف الصالح من المؤمنين، إذلم يبيحوا في جميع أمورهم أن يتولى عليهم من يخالف الكتاب والسنة إلى أحكام شهوته وهواه." تكوين رأي عام يستحق الحياة السياسية الحرة. وهو، بانتظار ذلك، يطالب بالمستبد العادل "مستبدٌّ يُكرِه المتناكرين على التعارف، ويلجيء الأهل إلى التراحم "هل يعدم الشرق كله مستبداً من أهله، عادلاً في قومه، يتمكن من العدل، أن يصنع في خمس عشرة سنة ما لا يصنع العقل وحده في خمسة عشر قرناً؟" ومعلوم أن العدالة لا تتم إلا بمشاركة المحكومين في الشؤون السياسية، فضلاً عن مشاركتهم في كل ما يعنيهم أمره، فلا يمكن أن يجتمع النقيضان: التفرد بالسلطة، والعدل الذي لا يتم إلا بالمشاركة. وهذا ما عبّر عنه (أديب إسحق) حين رأى أنه لا يصحّ "تسمية الدولة المستبدة مطلقاً بدولة متمدنة."55 وهو يعرّف الاستبداد بأنه: "تصرف واحد من الجماعة بدمائهم، وأمواهم، ومذاهبهم، بما يوجبه هواه، وما يقضي به رأيه، سواء كان ما يجري مخالفاً لمصلحتهم أو موافقاً لها."56 إن (أديب إسحق)، بهذا التعبير، يقطع الطريق على المستبدين الذين يتذرعون بمصلحة المواطنين لممارسة طغياغم، والتصرف وفق أهوائهم وآرائهم الشخصية. إننا، حتى الآن، نلاحظ أن الفكر العربي عرّف الاستبداد بأنه غياب القانون والكف عن المشورة، وهذا ولا شك جانب مهم من جوانب الاستبداد، لكنه ليس الجانب الوحيد لأن الاستبداد كثيراً ما يظهر في ظل القانون مرتدياً ثوب المشورة المزيّة والتداول المصطنع، وقد أدرك ذلك بعض مفكرينا، وإن بدرجات متفاوتة من الوعي.

كما لم تغب عن أذهاغم أنواع الاستبداد (وإن بشكل ضبابي) مهما اختلفت أسماؤه. فقد لاحظوا التفاوت في الثروة بين أفراد الأمة، والفساد الاجتماعي القائم، والشلل التربوي الذي أصاب المجتمع، وحظّر كل أنواع الحرية وتسمياتا، لاحظوا ذلك كله، وأطلقوا عليه أسماءً مختلفة وأوصافاً عدّة، واتِفقوا على وجوب التغيير والإصلاح.

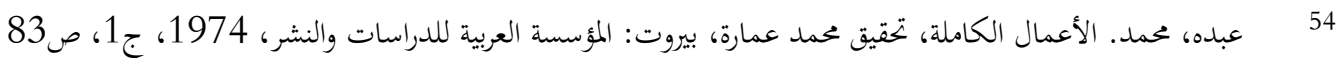

$$
\begin{aligned}
& 55 \text { } 56
\end{aligned}
$$

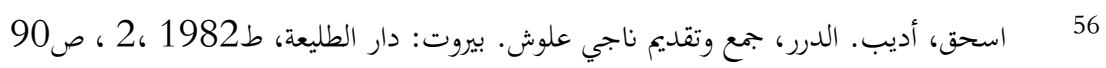




\section{ثالثاً :الكواكبي في طبائع الاستبداد:}

إن مفكّري اليقظة العربية، بدءاً من (الطهطاوي)، وإن اختلفت أساليبهم في الإصلاح، إلاّ أفمم اقتربوا

كثيراً من وصف الدّاء بأنه الاستبداد. وكان لا بد من بعض الوقت إلى أن يأتي الجيل الثّاني للروّاد الأوائل فيدفع بالفكرة قدماً لتصبح أكثر نضجاً ووعياً. من هذا الموقع برز الكواكبي مبيناً طبائع الاستبداد ومصارع

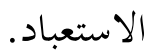

بدأ الكواكبي كتابه "طبائع الاستبداد" بالتعريف بموضوع بحثه، محاولاً أن يعطي الكلمة أبعادها:

"الاستبداد لغةً هو غرور المرء برأيه والأنفة عن قبول النصيحة أو الاستقلال في الرأي وفي الحقوق

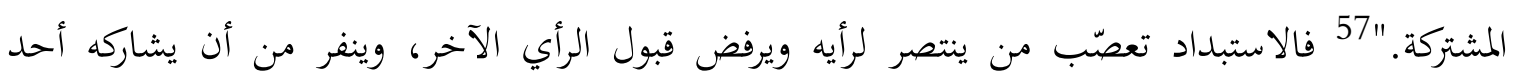
التفكير، أو هو استئنار المرء بالحقوق العامة لنفسه، تلك الحقوق التي يتوجب عليه أن يشارك الآخرين فيها. وهذا المعنى يشمل الاستبداد بصفة عامة حيث يكون الفرد، أياً كانت وظيفته، سواء أكان أباً أم معلماً أم حاكماً، ويسمى تبعاً لمضافه فيكون أسرياً أو تربوياً أو دينياً أو مالياً، لأن "تحكّم النفس على العقل، وتحكّم الأب والأستاذ والزوج، ورؤساء بعض الأديان، وبعض الشركات، وبعض الطبقات، فيوصف بالاستبداد مجازاً أو مع الإضافة."58 وهنا يبدو جلياً أن الكواكبي يدرس الاستبداد من حيث الهيئة الصادر عنها، أما الاستبداد باعتبار الوسيلة المستخدمة في إيقاعه على الآخرين، فإنه يتبدى من خلال المستبد وتصرفاته.

يقوم الكواكبي بدراسة نفسية المستبد، من خلال دراسة أخلاقه وممارساته وعلاقته بالمجتمع. كما أنه

$$
\text { يدرس صفات أعوانه وتصرفاتم. }
$$

فمَن ذا الذي يقوم بفعل الاستبداد، وكيف يرسم الكواكبي صورته؟ يستعرض الكواكبي آراء الآخرين في المستبد، دالاً بذلك على مشاركتهم فيما ذهبوا إليه من وصف للمستبد. فهو من: "يتحكم في شؤون الناس بإرادته لا بإرادتم ويهكمهم بهواه لا بشريعتهم."59 والكلمات التي تُستعمل مرادفاً للمستبد، مثل لئل

$$
\begin{aligned}
& 57 \text { الكواكبي، عبد الرمن. طبائع الاستبداد ومصارع الاستعباد. بيروت: دار القرآن الكريم، الناشر رياض كيالي، ط2، } 1973 \text { ، ص21 } \\
& 58 \\
& 59
\end{aligned}
$$


(جبار، وطاغية، وحاكم بأمره، وحاكم مطلق..)، لا تعني المؤلِّف كثيراً بقدر ما يعنيه فحواها: أي معرفة مجموعة الصفات التي إذا اتصف بها شخص ما حقّت عليه تلك التسمية. فهو يأخذها على أهما كلمات تدل على شخص واحد، يسميه (مستبدا)، لا يعنيه إلاّ أن تكون الرعية أذناباً له لا أكثر، وأن يكون الناس أدوات لتنفيذ رغباته. إن "المستبد يودّ أن تكون رعيته كالغنم درّاً وطاعةً،" ليس لهم من هدف إلا خدمة مصالحه. 60 ويريدهم فئة عبيد لا يسعهم إلا السجود أمام شخصه، ما داموا يعيشون في كنف دولته وتحت رعايته. 61

ويبين لنا الكواكبي كيف ينظر المستبد إلى نفسه وإلى الآخرين، فإن "المستبد في لحظة جلوسه على عرشه ووضع التاج على رأسه يرى نفسه كان إنساناً فصار إلهاً" 62 لا يُناقش ولا يُعصى له أمر ـ وهو، لعلمه لئه بسفالته، يحاول أن يغطي قصوره ودونيته بشتى الوسائل والأساليب. لكن "التمويهات التي يسترهب بها

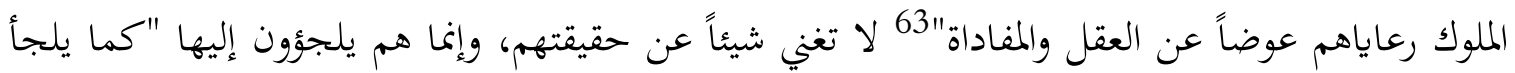
قليل العزّ للتكبر وقليل العلم للتصوّف وقليل الصدق لليمين وقليل المال لزينة اللباس." 64 فما هذه المظاهر القيصرية إلا أقنعة يرقمها المستبدون تعويضاً عن نقص، يعرفونه، في نفوسهم. لذلك فإن الجالس على العرش ترتعد فرائصه خوفاً من رعيته. ويدرك بما يعلمه عن نفسه من ظلم وتعسف، بأن الرعية قد بترّده من تاجه في أي لحظة. 65 لذلك فإنه يستعين بأظلم الناس ممن يثق بأفم على شاكلته، لردع من تُسوِّل له نفسه دفع الظلم أو ردّ الطغيان. 66 فينشئ جيشاً من المستبدين الصغار. "إن المستبد لا يخرج قط عن أنه خائن خائف محتاج لعصابة تعينه وتحميه فهم ووزراؤه كزمرة لصوص: رئيس وأعوان"67 ولا يلبث أن يتخوف المستبد حتى من رني أعوانه، فضلاً عن خوفه من رعيته "لأن أكثر ما يبطش بالمستبدين حواشيهم لأن هؤلاء أشقى خلق الله

$$
\begin{aligned}
& 60 \\
& 61 \\
& 62 \\
& 63 \\
& 64 \\
& 65 \\
& 66 \text { } 66 \\
& 67
\end{aligned}
$$


حياة، يرتكبون كل جريمة وفظيعة لحساب المستبد."68 فيحاول تنحيتهم والقضاء عليهم وبذر الفتن بينهم حتى لا يتفقوا عليه. والمستبد يوهم الناس، عن طريق التنكيل بأعوانه، بأنه صالح عادل، وأن مساعديه ووزراءه هم الأشرار. وكثيراً ما يصدقه الناس متناسين أن المستبد هو الذي عيّن هؤلاء المساعدين والوزراء الأشرار.

هكذا يرسم (أبو الضعفاء) صورة المستبد، فهو كلما زاد خوفه ازداد بطشه في محاولة منه للحفاظ على نفسه. وكلما زاد ظلماً واعتسافاً "زاد خوفه من رعيته وحتى من حاشيته، حتى ومن هواجسه وخيالاته" حيث تصور له نفسه أن كل من يجيط به يسعى إلى قتله. ويبقى غارقاً في الدوامة نفسها، لما يعهده في نفسه من تعوّد على خيانة العهود وظلم الناس، فيخاف حتى من الهواء الذي يتنفسه ويحسب له حساباً. نتيجة لذلك يرى الكواكبي أن "أكثر ما ثُختم حياة المستبد بالجنون التام"، 70 ويعلّق على ذلك: "قلت الت التام لأن المستبد لا يخلو من الحق قط، 71 لأن عقله سيبقى يجتر معارفه الأولى فقط، بسبب أسلوبه الاستبدادي في

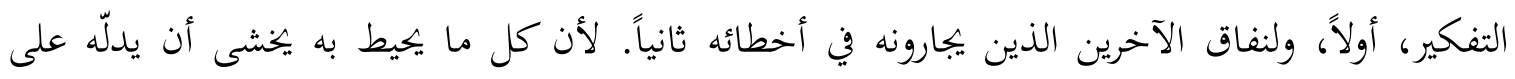
صواب الطريق، فما يخالف رأيه، فيفقد رأسه أو مركزه. لذا فإن المستبد، خلال حكمه كله، يبقى يخبط خبط

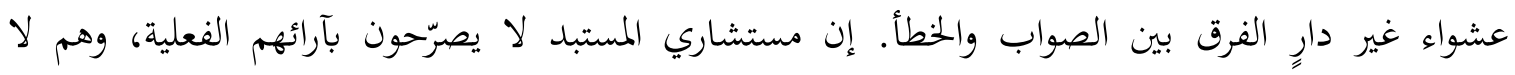
ينفكّون يحاولون استنتاج ما يريد المستبد أن يقولوه فيدلوه به على أنه رأيهم. لذلك حقّ القول: "إن الصدق لا يدخل قصور الملوك"، 72 مما يبعل الخطأ يجر الذي بعده إلى أن يصبح عقل الملك (= المستبدّ) مشوشاً مضطرباً يداخله الخبل إلى أن ينتهي بالجنون، ما لم يُنه بطريقة أخرى. ذلك فضلاً عن أنه يبقى طوال حياته أشقى الناس عيشاً وأتعسهم فكراً وروحاً. 73

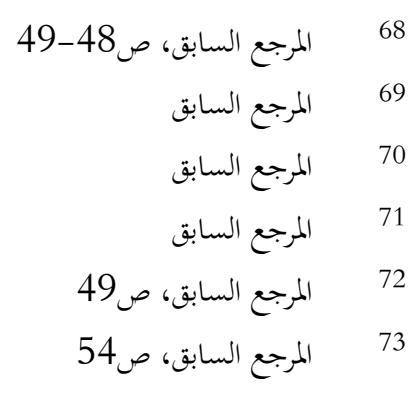


ولكن ما صفات الأعوان-الأعيان، كيف يعيشون، وكيف يفكّرون، وكيف يختار المستبد أعوانه؟ يجيب الكواكبي: إن المستبد يحرص على أن يكون أعوانه من حثالة المجتمع، ويجفظ لهم مراتبهم الوظيفية على بلى هذا الأساس بحيث "يكون أسفلهم طباعاً وخصالاً أعلاهم وظيفة وقرباً، ولذا لا بد أن يكون الوزير الأعظم للمستبد هو اللئيم الأعظم في الأمة"، 74 ذلك ليتمكن من تسليطه على رقاب الناس، وهو على يقين بأن هذا الشخص وأمثاله لن تأخذهم الرأفة بأحد، ولن (يعصوا) لمولاهم أمراً يشم فيه رائحة الدم والانتقام "إن

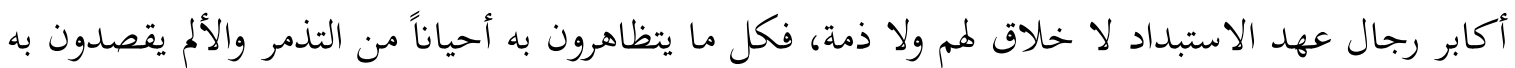
غشّ الأمة"، 75 معتمدين على أن الاستبداد قد أعمى بصر الأمة وسهّل غشّها، لذلك فهُم يتبجّحون كذباً بأغم هم الذين سيغيرون الأوضاع، وأفم فقط ينتظرون الفرصة السانحة، وهم في الواقع يبتغون تثبيط عزائم الناس وامتصاص ثورات غضبهم. وهؤلاء المخادعون جبناء مرتشون، وما ثروقم المكدسة إلا من السرقات المسموح بها في عهد الاستبداد، وما هم إلا فخورون "بمشاركة المستبد في امتصاص دم الأمة، ذلك بأخذهم العطايا الكبيرة والرواتب الباهظة"، 76 وهم يتصدّقون بالقليل، وقد يشاركون في بناء المعابد سمعةً ورياءً، "وكأفم يريدون أن يسرقوا أيضاً قلوب الناس، بعد سلب أمواهم، أو أغم يرشون الله، ألا ساء ما يتوهمون."77

والمستبد لا يفتأ يزيد من عدد أعوانه باطراد مع زيادة جوره على مواطنيه، فلا يلبث أن يعمّ الاستبداد أسلوباً للعيش، ذلك لأن كل فرد من أفراد الدولة، وخاصة المقربين من كراسي الحكم، يحاولون أن يتمثلوا أفعال المستبد الأكبر، وأن يحذوا حذوه، فينتشر الاستبداد في أنحاء الدولة كلها "الحكومة المستبدة تكون طبعاً مستبدة في كل فروعها من المستبد الأعظم إلى الشرطي، إلى الفرّاث، إلى كنّاس الشوارع، ولا يكون كل صنف إلا من أسفل أهل طبقته أخلاقاً لأن الأسافل لا يهمهم طبعاً الكرامة وحسن السمعة، إنما غاية

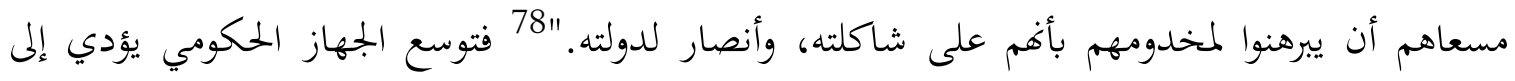
زيادة عدد الذين يستبدون بالقرارات تحت ستار حماية الدولة، ويزداد، بالتالي، عدد الذين ينبغي للمواطنين

$$
\begin{aligned}
& \text { 74 } \\
& 75 \\
& 76 \\
& 77 \\
& 78 \text { المرجع السابق، ص62-63 }
\end{aligned}
$$


أن يطيعوهم "وهذه الفئة المستخدمة يكثر عددها ويقل حسب الاستبداد وخفّنه، فكلما كان المستبد حريصاً على العسَف احتاج إلى زيادة جيش المتمجدين العاملين له المحافظين عليه."79 هكذا يتشكل هرم الاستبداد من القمة إلى القاعدة "ولو نظر السائل نظرة الحكيم المدقق لوجد كل فرد من أسراء الاستبداد مستبداً في نفسه لو قدر لجعل زوجته وعائلته وعشيرته وقومه والبشر كلهم حتى وربّه الذي خلقه تابعين لرأيه وأمره."80 فالاستبداد، في فكر الكواكبي، ليس حاكماً يأمر وينهي، بل هو نظام يشمل المجتمع كله. فالحاكم مستبد، وأعوانه مستبدون، وأسرى الاستبداد يتخبطون في رد فعل استبدادي كلٌّ بحسب ما يتسنى له، ولا يبقى ما دون مستوى هذه القاعدة إلا المنبوذون، أولئك الذين عليهم أن يحملوا عبء هذه الطفيليات التي تتكاثر وتتوالد بشكل سرطاني مخيف.

ويصور الكواكبي الحياة الجسمية والروحية والعقلية والاجتماعية لمن يقع عليهم الاستبداد، الذين يوصفون بأفم (أسرى، ومستصغرون، وبؤساء...) إن أسير الاستبداد لا نظام في حياته كلها، فأنّ يكون له نظام في أخلاقه! إنه يشبّ في ظل الحكم الاستبدادي الذي لا يغذيه إلا بشرّ الخصال، فيتعود الرياء والكذب، ويستعملها مع ربّه وأسرته وقومه، وحتى مع نفسه. 82 وتتشرب نفوس الأسرى المساوئ، وتترسخ فيها تعاليم الاستبداد القائمة على الخنداع والنفاق والاتكالية "وهكذا طول الألفة على هذه الخصال قلب في تفكيرهم الحقائق وجعل عندهم المخازي مفاخر، فصاروا يسمّون التصاغر أدباً، والتذلل لطفاً، 83 فتركوا حقوقهم ورضخوا للظلم وقبلوا الإهانة حتى فسدت أخلاقهم حيث لا إرادة لهم ولا خيار، وتعودوا على كلى الخصال السيئة التي تضعف الثقة بالنفس وبالآخرين، فقلَّ أهل العمل منهم، وأهل العزائم. لماذا يعملون وحياعم بغير انتظام وليس لديهم الحد الأدنى من الضمان النفسي الضروري الذي يحثّ على العمل، ولا ضمان في أن يحتفظ الإنسان بما جنته يداه؟

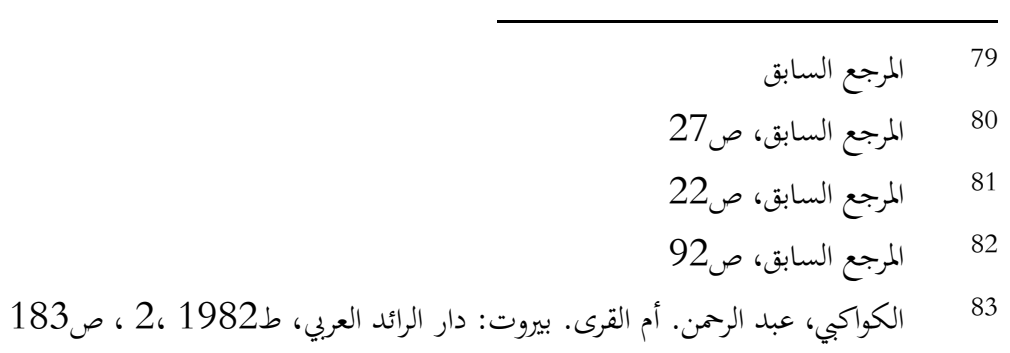


إن الإنسان الذي يصفه الكواكبي، في ظل الاستبداد، إنسان مسلوب الإرادة يتصرف أسياده بمقدراته جميعها. إنه فاقد المواطنية لأنه لا يحب وطنه الذي لا يأمن على الاستقرار فيه. ولا أمل له ولا غاية، يعيش في فراغ ميت. مسلوب الوعي بالمستقبل فلا يهتم إلا بحفظ بقائه في لحظته الآنية، لأنه لا يملك ما هو جدير بالحفاظ عليه. وأسير الاستبداد معرّض لسلب المال والشرف في أي وقت، لذلك تقل همّته على العمل، وأمله الوحيد هو أن يحتفظ بالقليل مما يحصله من المال محاولاً إخفاءه عن أعين الناس والتظاهر بالفقر والفاقة خوفاً من فقدانه. 84 "ولهذا ورد في أمثال الأسراء، أن العاقل من يخفي ذهبه وذهابه ومذهبه، وأسعد الناس الصعلوك الذي لا يعرف الحكام ولا يعرفونه"، 85 فليس أمام الناس، في ظل حكم استبدادي، إلا التكتم والتقيّة والحيلة لإخفاء أمواهم خشية فقداها في زمن يسمح الحكّام فيه بالنهب والسلب. كما يضطر الناس إلى إخفاء مقاصدهم وتحركاتم وآمالهم، فضلاً عن اضطرارهم إلى إخفاء أفكارهم ومعتقداقم، لأن كشف ما لا يرضى عنه المستبد يعرّض حامله إلى السجن والتعذيب، وربما القتل. هؤلاء الناس، بحسب رأي الكواكبي، ليس لهم إلا التقوقع داخل ذواقم حتى يتجنبوا -قدر إمكاغم- يدَ المستبد التي تمتد بالإهانة والسلب والتسلط على كل ما تطاله؛ لأن المستبدّ لا يفرِّق بين صديق أو مُعين، وعدو معارض مشاكس. إن المستبد حينما يلمح عند أحد ما شيئاً ينقصه هو، أو شيئًا يجعل الآخر متميزاً عليه، فإنه يُسارع إلى سلبه إياه، والاستئثار به لنفسه، فلا الناس يريدون مناصرة المستبد مباشرة، ولا هم يماولون محاربته، وإنما حرصهم كلّه ينصبّ على ملذاتم البهيمية. والكواكبي يلاحظ أنه لا فرق بين غنيّ وفقير في الشقاء زمن الاستبداد، ويشرح ذلك قائلاً: إن "أسراء الاستبداد حتى الأغنياء منهم كلهم مساكين لا حراك فيهم، يعيشون منحطين في الإدراك، منحطين في الإحساس، منحطين في الأخلاق"86 لأفم جميعاً هدف تسلّط المستبد الذي يريد أن يستخدمهم كالأنعام لأغراضه الشخصية، وكأفم جميعاً حُلقوا لخدمته.

إن الأمة المستبَدّة، بأغنيائها وفقرائها، تعيش في وطن لا تملك منه شيئاً، وإن الذي يستأثر بخيرات البلاد، كلها، هو المستبدّ الذي يوزع على أعوانه ما يشاء. أما المواطنون فلا حقوق لهم في موطنهم، وما هم

\begin{tabular}{|c|}
\hline المرجع السابق، ص111 \\
\hline المرجع السابق، ص80-81 \\
\hline
\end{tabular}


إلا أشياء، شأفم في ذلك شأن الأشياء الأخرى، كالشجر والحيوانات والأموال، وما هم إلا وسيلة يتوسلها المستبد ليرضي أهواءه الخاصة، ويشكلها وفق مزاجه الشخصي. إن حياة هؤلاء البؤساء كلها خلل في خلل، وذلك يجعلهم هيّني النفوس، يعتقدون أغم لا يستحقّون حتى الفتات الذي ينعم عليهم به المستبد، ويرون أنفسهم جاهلين عاجزين لا يمكنهم العيش إلا بمساعدة آسرهم. ويعيش الأسير في بلبلة فكرية، مختل الشعور، غير قادر على التمييز بين الخير والشر، مريض الجسم يشيخ قبل أوانه لا ناموس له ولا إرادة، كالحيوان "ومن أين لأسير الاستبداد أن يكون صاحب ناموس وهو كالحيوان مملوك العنان، يقاد حيث يراد، ويعيش كالريش يهب حيث يهب الريح، لا نظام ولا إرادة."87 يساعده المستبد في تغليب نفسه على عقله، حتى يزيغ بعيداً عن كل ما يمت إلى التربية والعلم والنظام بصلة، ويغرق في الوهم وفساد التصورات. "بناء عليه ما أبعد الناس المغصوبة إرادقم، المغلولة أيديهم، عن توجيه الفكر إلى مقصد مفيد كالتربية."88 إن عبيد السلطة الاستبدادية غير مالكين أنفسهم، ويعملون، إن عملوا، من دون إيمان أو هدف، لذلك فهم أبعد الناس عن أن يوجد فيهم من يُعنى بالتربية.

إن طفل الأسر ينشأ على تلقي المشاكسة والمخاصمة، يعاني وهو طفل من ضغط القماط، وضيق الفراش، والغذاء الفاسد "وإذا افتكرنا كيف ينشأ الأسير في البيت الفقير وكيف يترب، نجد أنه يلقح به وفي

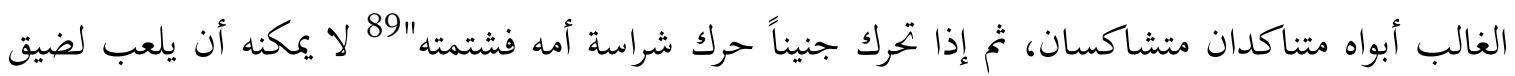
مساحة البيت وعصبية والديه مما يعانيانه من ضغط الأسر، ولا يستطيع أن يستفسر عما يريد فهمه خشية أن يُضرب أو يُزجر لضيق خُلق أبويه وجهلهما. ثم يألف القذارة وصيغ الشتائم التي يتعلمها من زملائه في المدرسة، بعدئذ يتولى المستبدون إكمال إفساده بالتضييق على عقله ولسانه "وهكذا يعيش الأسير من حين يكون نسمة في ضيق وضغط، يهرول ما بين عتمة هم ووادي غم، يودع سقماً إلى أن يفوز بنعمة الموت

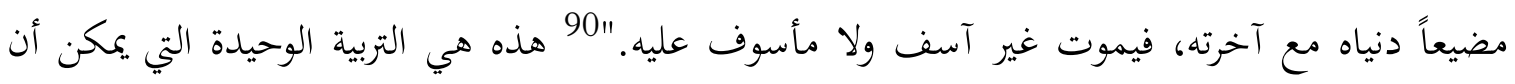
يتلقاها الواقع تحت سطوة الاستبداد منذ أن يكون نطفة إلى أن يُوارى تحت التراب؛ لأنه يبقى محاصراً طيلة

\begin{tabular}{|c|c|}
\hline المرجع السابق، ص88-89 & 87 \\
\hline المرجع السابق، ص106 & 8 \\
\hline المرجع السابق، ص108-109 & \\
\hline المرجع السابق، ص109 & \\
\hline
\end{tabular}


فترة وجود الاستبداد. إن الأسير لا يوجد مستقلاً بذاته، وإنما هو نكرة لا يوجد إلا بالإضافة إلى آسره، يتبعه فيما يأمره به وينتهي عما ينهاه عنه؛ لا وظيفة له إلا أن يكون عصاً في يد المستبدّ، يستخدمها أينما شاء وكيفما أراد، فيعيش الأسير فاقد الوظائف الاجتماعية والشخصية، وتصبح حياته لا معنى لها، إن "حياة الأسير تشبه حياة النائم المزعوج بالأحلام، فهي حياة لا روح فيها"91 إذ لا يمكنه أن يريد شيئا، فضلاً عن استحالة تحقيق ما يريده. ولا يستطيع أن يرى إلا بعيني آسره، يعزو كل فضل إلى كرم الحاكم، ويسند كل شر إلى استحقاقه إياه، ويعتقد أن الله يعاقبه على أعماله إذ يسلّط عليه سياط المستبدّين. 92

إن الأسرى يتأقلمون ووضع الاستبداد ومتطلباته، فهذا الوضع قد: "جعل الرعية خادمة للرعاة فقبلوا وقنعوا"، 93 ولم يقوموا إلا برد فعل سلبي بجاه الظلم الواقع عليهم، فيقابل واحدهم التجبر عليه بالتذلل والتصاغر، وإذا تصادف أن طالب الأسير بحق من حقوقه فإنه يفعل ذلك على صيغة استعطاف، وكأنه يطلب إحساناً لا حقاً. والأسير يتهاون في حقوقه، حتى إذا ضُرب أو شُتم فإنه يتصرف سلبياً، فهو إما أن يتجاهل ذلّه، أو يلجأ إلى مداواته بتعطيل إحساساته بالمخدرات والمسكرات، أو بالتظاهر بأن الدين يأمر بالتسامح، فيسلك مسلك الرياء والنفاق، 94 ويردد مع المرددين بأن الدنيا سجن المؤمن، وأن المؤمن مصاب، وأن الله إذا أحب عبداً ابتلاه، إلى غير ذلك محا أدخله في أذهاهم مثبّطو العزائم، ورافعو لواء الاستبداد. 95

ومن طبع الأسير الخمول والكسل، فما من هدف يُطلب، وما من أمل يُرجى تحقيقه "فيعيش خاملاً خامداً ضائع القصد، حائراً لايدري كيف يميت ساعاته وأوقاته"، 96 يغري نفسه بالسعادة الأخروية "ويبعد عن فكره أن الدنيا عنوان الآخرة، وأنه ربما كان خاسر الصفقتين."97 فلا هو يجيا دنياه، ولا هو ينفّذ ما يطلبه منه دينه ليسعد في آخرته. إنه إنسان تائه، يؤمر بمعاداة أهله وجيرانه، فينفّذ ما أمر به خشية غضب

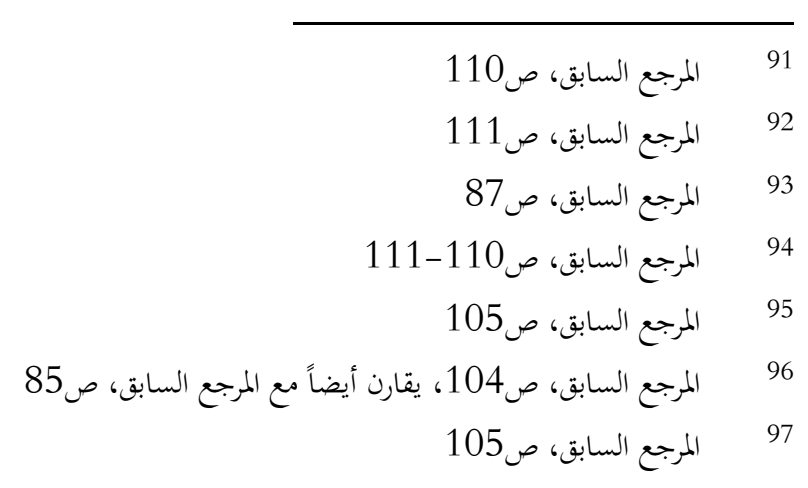


المستبد عليه، لذلك يعيش فرداً معزولاً عمن حوله، متوجساً منهم، مترصداً لاستغلال هفواتم في صالحه. وأنّ لأناس هذه معيشتهم أن ينعموا بفوائد التعاون والتضامن؟ "إن الأسراء محرومون طبعاً من ثثرة الاشتراك بكردي في أعمال الحياة، يعيشون مساكين بائسين متواكلين متخاذلين متقاعسين متفاشلين." "98 إن الشراكة تتطلب إرادة الشركاء، والإرادة تتضمن الحرية، وهذان الشرطان غير متوافرين في زمن سيادة الاستبداد، وإنما الذي يوجد هو حثّ على التناحر حيث يحمّل كل أسير أخاه مسؤولية ما هو فيه من مصائب.

هذه هي الصورة التي رسمها الكواكبي لأسرى الاستبداد. صورة قاتمة ترافق الأسير بدءاً من مولده حتى ينال ما يرجوه بالتخلص من هذه الحياة الشقية بالموت، ظناً منه بأن الاستبداد الذي يمكمه قضاء لا مفرّ له منه، وبلاء لا قدرة له على مجاهته. إن تصوير الكواكبي المستبدَّ لتصويرٌ عميق يدل على فهم النفس ئس الإنسانية. فالمستبد مريض يحاول تعويض نقصه عن طريق تحطيم التماثيل الجميلة. وهذا التصوير الذي يورده الكواكبي، يستدعي أن تخرج من دُرج الذاكرة نظرية (إدلر) حول التعويض و (إرادة القوة) إذ يلجأ مَن يشعر بضعفه إلى (التعويض عن الشعور بالنقص) بالمغالاة في بعض الأمور، وإن لم يتمكن من التعويض، ولن يفعل، فإن صاحبه يصاب (بالعصاب) ويحاول أن يتميز عن الآخرين، عن طريق الانتقام منهم، مادام عاجزاً عن أن يكون طبيعياً مثلهم.

يرى إدلر (Adler) أن الاستبداد قد يرجع إلى شعور ذاتي بخيبة الأمل والإحباط، وهكذا "يحاول الضعفاء والأغبياء والفاشلون التخلص من شعورهم بالنقص عن طريق إذلال الآخرين وإخضاعهم." فالرغبة في السيطرة، والميل إلى التسلط، ثمرة ضعف نفسي وبلبلة داخلية. يقول (إريك فروم Erek Froum بأفعاله، وعن فرض احترامه على الآخرين، يلجئه إلى إخفاء عجزه وراء موقف مناقض لحقيقته. 101 ويحاول

$$
98
$$

99 دوفرجيه، موريس. علم الاجتماع السياسي، عن: عصمت سيف الدولة، الاستبداد الديعراطي، بيروت: دار الكلمة للنشر، 1981 ،

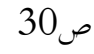
دوهاميل، اوليفر. تاريخ الأفكار السياسة، ترجمة خليل أمدد خليل: بيروت: معهد الإنماء العرب، كتاب الفكر العربي، 1984 ، 100

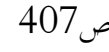
دوفرجيه، موريس. مدخل إلى علم السياسة، ترجمة سامي دروبي وجمال أتاسي، دمشق: دار دمشق، 1964 ، ص43 101 
تغطية عجزه فيقع فريسة شتى الأمراض النفسية. وهذا ماحاول الكواكبي قوله من خلال تحليله شخصية المستبد وتصوير خوفه من رعيته. 102

يرى (فرايرى)، بجق، "أن نزعة القاهرين في امتلاك كل شيء حتى الإنسان هي ضرب من

السادية"، 103 وهذا ما حاول الكواكبي قوله من خلال وصفه شقاء المستبد واضطراب تفكيره نتيجة فقدانه نصائح العلماء المخلصين (فالاستبداد يقيم حاجزاً عقلياً ونفسياً بين المستبد وبين رعاياه مما يجعل المستبد يعيش في عزلة تامة، فتجتمع له من الجهل والتعظيم والعزلة كل أسباب المرض الذي يسمونه "جنون العظمة" والذي تصدر عن صاحبه أغرب التصرفات وأكثرها حمقاً 104 وهذا ما يسميه (ألبير ميمي): "العقدة النيرونية" " Nairon Complex" عمل يدينه. ويشعر بالحاجة إلى غسل يديه من انتصاره، ومن هنا يبذل جهداً كبيراً في تزيين (بل تزييف) التاريخ، وإعادة كتابة النصوص، وإطفاء مخزون الذاكرة، إنه يجهه نفسه لكي يهوّل الاغتصاب إلى عمل مشروع.

إن هذا الركض اللاهث، خلف النفس المتوارية أبداً، يحطم بقايا إنسانية المستبد، ويجعل منه ظلاً يفتقر إلى الإشباع ويبحث طويلاً عن الشرعية المفقودة " فإذا لم يكن المستبد سعيداً، فذلك لأنه ليس غير معترف به." 106 فالمشكلة ليست جزئية، ولا هي مجرد الحصول على درجات متدنية في بعض المواد المقررة على لئ الحاكم. إها، بإيجاز شديد، وضع الأمور في غير مواضعها، مما يجعل أي بحث فيها غير ذي جدوى مالم تتم

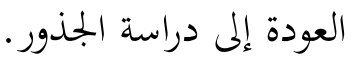

والكواكبي، من خلال دراسته شخصية المستبد، أكد أن الاستبداد مرض، وأن المستبد إنسان مريض. وسلّط الضوء على العلاج الشافي من هذا المرض، من خلال بحثه ظروف الاستبداد وتقلبات المستبد. إن

$$
\begin{aligned}
& 102 \\
& 103 \\
& 104
\end{aligned}
$$

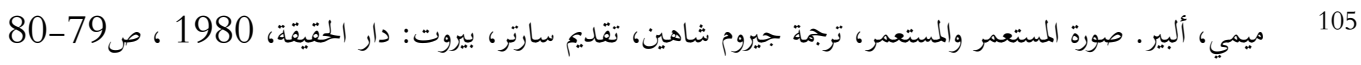

$$
\begin{aligned}
& 106
\end{aligned}
$$


الذي يُخرج المريض من أزمته ليس هو المصاب نفسه، وأما الشفاء يأتي عن طريق الجماهير المدركة حدود الداء، والعارفة بأعراضه، والشاعرة بثقل وطأته وفساد تصرفاته.

إن الاستبداد لا يلحق الأذى بالمقهورين فحسب، بل يمتد بالأذى إلى القاهرين أيضاً، إنه يشلُّ المستبدين والمستبد بهم معاً لأنه يشلّ قدرقم على أن يمارسوا وجودهم البشري كآدميين. إن الكواكبي قال ذلك كله، لو تسنى له الاستمرار في بحث شخصية المستبد لأمكنه القول بما نتج عن استقصاء أجراه (آدورنو (Adorno الذي يستبد فيه.

خاتمة:

من كل ما سبق يمكننا القول إن الاستبداد، من حيث الهيئة الصادر عنها، هو في النهاية استبداد سياسي مدجج بالسلاح والفكر والمال، وإن بدا مبدئياً على شكل استلاب فكري أو استغلال اقتصادي، والاستبداد، من حيث من يقع عليهم، هو استبداد اجتماعي، والاستبداد، من حيث الوسيلة المستبَد بها، هو فكري أو اقتصادي أو عسكري، الاستبداد، من الجهات والحيثيات كلها، هو صيغة للحياة والعلاقات في الدولة كلها. إن ما يحفز الشعب على الثورة ضد الاستبداد، الذي يلحق به شتى أنواع الظلم والارهاب، ليست الأفكار النظرية، التي تحثهم على نيل حقوقهم، وحدها، خاصة وأن عامة الناس لا تقرأ ما يُكتب، وإنما أيضاً معاناة القهر الحقيقية مما فُرض عليهم من التزامات جمّة وهم يفتقرون حتى إلى الحبز اليومي. لكن ليست تلك الأفكار ولا خواء الجيوب هو الذي يجعل الثورة أمراً ممكناً. إن الناس يصبحون مهيئين للمشاركة في عملية التغيير عندما يشعرون بأغم في حاجة ملحِّة إلى حقوقهم أكثر من الحبز، وعندما يدركون أن الحكومة هي المسؤولة عما يعانونه من عذاب. وهذه المعرفة تتكون من انسحاقهم تحت عجلات الواقع المرّ، وشعورهم به الذي تعززه الأفكار التي تشيع عن الحريات وحقوق المواطن في العيش الكريم. إن هذا الأمر لا يحدث بين ليلة وضحاها، وإنما يحتاج إلى وقت طويل حتى تنتقل تلك الآراء المتحررة إلى الرأي 
العام، كما يحتاج إلى جهد مضنٍ يبذله مفكرون جادّون بحدون تظل أفكارهم تحفر داخل مجتمع يعاني من

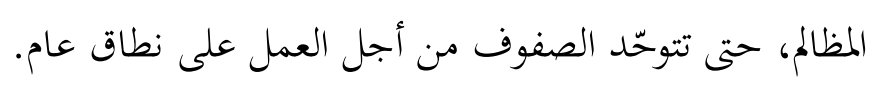

والإطاحة بالنظام الاستبدادي يلزمها علم يتناسب عكساً مع مستوى الضغط الاستبدادي الحاصل. وكلما كثرت المعاناة يقلّ مستوى المعرفة المطلوبة لتفجير الثورة على الاستبداد. أما في المجتمع الجاهل فيحتاج الشعب إما إلى ضغط استبدادي أكبر مما هو قائم وإما إلى الرفع من مستوى معرفته، حتى يدرك أن الحكومة هي علّة مأساته، ويسعى إلى تغييرها. إن تطور المجتمع أدى إلى تطور السلطة، وبالتالي فإن زيادة تطور المجتمع أمر لازم لتطوير السياسة.

والذي حدث، في زمن الكواكبي وبعده، هو أن منظّري الاستبداد كانوا وما يزالون يقومون بتحويلٍ تشرف الحكومة على تثبيته، بحيث يصبح مردّ الاستبداد هو غضب الله على الشعب الغارق في الذنوب حتى

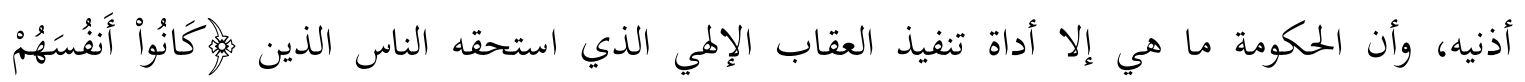

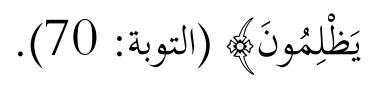

